\title{
Glucose-dependent activation, activity, and deactivation of beta cell networks in acute mouse pancreas tissue slices
}

\author{
Andraž Stožer ${ }^{1}$, Maša Skelin Klemen ${ }^{1}$, Marko Gosak ${ }^{1,2}$, Lidija Križančić Bombek ${ }^{1}$, Viljem Pohorec ${ }^{1}$, Marjan Slak \\ Rupnik $^{1,2,3 *}$, Jurij Dolenšek ${ }^{1,4^{*}}$ \\ ${ }^{1}$ Institute of Physiology, Faculty of Medicine, University of Maribor, Taborska ulica 8, SI-2000 Maribor, Slovenia \\ ${ }^{2}$ Center for Physiology and Pharmacology, Medical University of Vienna, Schwarzspanierstraße 17A, 1090 Vienna, Austria \\ ${ }^{3}$ Alma Mater Europaea - European Center Maribor, Slovenska ulica 17, 2000 Maribor \\ ${ }^{4}$ Faculty of Natural Sciences and Mathematics, University of Maribor, Koroška cesta 160, SI-2000 Maribor, Slovenia \\ * corresponding authors
}

\begin{abstract}
Many details of glucose-stimulated intracellular calcium changes in beta cells during activation, activity and deactivation, as well as their concentration-dependence, remain to be described. Classical physiological experiments indicated that in islets functional differences between individual cells are largely attenuated, but recent findings suggest considerable intercellular heterogeneity, with some cells possibly coordinating the collective responses. To address the above with an emphasis on heterogeneity and describing the relations between classical physiological and functional network properties, we performed functional multicellular calcium imaging in mouse pancreas tissue slices over a wide range of glucose concentrations. During activation, delays to activation of cells and first responder-any cell delays shortened, and the sizes of simultaneously responding clusters increased with increasing glucose. Exactly the opposite characterized deactivation. The frequency of fast calcium oscillations during activity increased with increasing glucose up to $12 \mathrm{mM}$ glucose, beyond which oscillation duration became longer, resulting in a homogenous increase in active time. In terms of functional connectivity, islets progressed from a very segregated network to a single large functional unit with increasing glucose. A comparison between classical physiological and network parameters revealed that the first-responders during activation had longer active times during plateau and the most active cells during the plateau tended to deactivate later. Cells with the most functional connections tended to activate sooner, have longer active times, and deactivate later. Our findings provide a common ground for recent differing views on beta cell heterogeneity and an important baseline for future studies of stimulus-secretion and intercellular coupling.
\end{abstract}




\section{Introduction}

Glucose is the main insulin secretagogue in beta cells. After entering beta cells through GLUT (131) or other transporters (117), glucose initiates cellular processes leading to transient activation of beta cells, followed by subsequent periodic oscillatory changes in membrane potential and intracellular calcium concentration $\left(\left[\mathrm{Ca}^{2+}\right]_{\mathrm{IC}}\right.$, as well as insulin secretion $(22,23$, $61,72,111,138)$. The calcium ion $\left(\mathrm{Ca}^{2+}\right)$ is the central secondary messenger, coupling stimulation by nutrients and many other neurohormonal stimuli with secretion $(58,73,75$, 131). Glucose-dependent oscillatory $\left[\mathrm{Ca}^{2+}\right]_{I C}$ changes have been reported in beta cells in vivo in an exteriorized pancreas and in islets transplanted into the anterior eye chamber, in situ in acute pancreas tissue slices, and in vitro in enzymatically isolated and cultured islets and isolated cells $(17,19,23,26,33,54,69,134,135)$. [ $\left.\mathrm{Ca}^{2+}\right]_{\text {IC }}$ oscillations are the intermediate or central step in beta cell stimulus-secretion coupling. On the one hand, they are well synchronized with membrane potential oscillations or so-called bursts of electrical activity (47, $59,125)$. On the other hand, they are the triggering signal for the fusion of insulin-containing vesicles with the plasma membrane, thus driving the periodic release of insulin $(23,60,61)$. The extent of insulin secretion is further regulated by various additional signals in both $\left[\mathrm{Ca}^{2+}\right]_{1 \mathrm{C}^{-}}$ dependent and $\left[\mathrm{Ca}^{2+}\right]_{\mid \mathrm{C}}$-independent manner $(1,29,73,131)$. Regardless of the pathways taken to induce and regulate insulin secretion, $\left[\mathrm{Ca}^{2+}\right]_{I C}$ remains a convenient proxy for assessing both more proximal and more distal events in the stimulus-secretion coupling cascade. Compared with measurements of proximal membrane potential changes and distal insulin secretion, at present high frequency confocal functional multicellular $\left[\mathrm{Ca}^{2+}\right]_{\mathrm{IC}}$ imaging typically offers the best combination of the number of cells that can be analyzed simultaneously, spatial and temporal resolution, and total recording time $(2,43,46,66,101$, $139,140,146)$.

Beta cells within an islet typically display a biphasic $\left[\mathrm{Ca}^{2+}\right]_{1 \mathrm{c}}$ response to physiological stimuli $(23,59,67,101,110,139,140,142)$. From a temporal perspective, this biphasic $\left[\mathrm{Ca}^{2+}\right]_{\mathrm{IC}}$ response is well in accordance with the biphasic insulin release observed in vitro in isolated islets $(13,60)$. An initial transient increase in $\left[\mathrm{Ca}^{2+}\right]_{\mathrm{IC}}$ is followed by a sustained plateau phase with superimposed fast $\left[\mathrm{Ca}^{2+}\right]_{\mathrm{IC}}$ oscillations. The frequency and duration of these fast $\left[\mathrm{Ca}^{2+}\right]_{\mathrm{IC}}$ oscillations closely resemble electrophysiologically measured bursts of mebrane potential depolarizations, as well as fast pulses of insulin secretion $(11,22,24,47,59,61,125)$. During the transient phase, the initial activation of cells varies significantly in time and space. Beta cells activate in small clusters dispersed over an islet with no predictable pattern $(47,67,142)$. During the plateau phase, $\left[\mathrm{Ca}^{2+}\right]_{\mathrm{IC}}$ oscillations are slightly phase-lagged due to intercellular depolarization, and $\left[\mathrm{Ca}^{2+}\right]_{\mathrm{IC}}$ waves repeatedly spread across islets with an average velocity of about $100 \mu \mathrm{m} / \mathrm{s}(10,19,30,47,80,129,139,143)$. Simultaneous measurements of membrane potential and $\left[\mathrm{Ca}^{2+}\right]_{\mathrm{IC}}$ oscillations demonstrated a tight coupling of the two processes $(16,59$, 125), with membrane potential depolarization preceding the $\left[\mathrm{Ca}^{2+}\right]_{\mathrm{IC}}$ increase by about $150 \mathrm{~ms}$ (47). After lowering glucose back to substimulatory concentration, beta cells in all types of preparations deactivate, and $\left[\mathrm{Ca}^{2+}\right]_{\mathrm{IC}}$ returns to the basal level, $(39,81,101,139,140)$.

A substantial number of previous studies attempted to address the glucose-dependency of beta cell stimulation; however, a complete characterization of the complex relationship with 
stimulus intensity remains elusive. Both ex vivo $(9,20,41,57,74,97)$ and in vivo experiments (74) show that activity, assessed by measurements of membrane potential, $\left[\mathrm{Ca}^{2+}\right]_{\mathrm{IC}}$, or insulin secretion, progressively increases over a wide range of physiological and supraphysiological glucose concentrations. In dissociated beta cells in culture, glucose thresholds for single beta cell activation of $\left[\mathrm{Ca}^{2+}\right]_{\mathrm{IC}}$ differed substantially among individual beta cells, ranging from low to supraphysiological glucose concentrations. Increasing stimulus intensity progressively recruited additional beta cells into a secretory response $(20,85,130)$, a phenomenon well explained by beta cell heterogeneity with respect to their sensitivity to glucose $(50,91,142)$. However, beta cells in intact islets function in a coupled, collective way and such coupling significantly narrows the concentration range over which the whole islet activates. The halfmaximal effective concentration of glucose $\left(\mathrm{EC}_{50}\right)$ demonstrated for $\left[\mathrm{Ca}^{2+}\right]_{\mathrm{IC}}$ and membrane potential is about $7 \mathrm{mM}$, and the most significant increase in electrical activity in the range of about 6-8 $\mathrm{mM}(20,40)$, indicating that additional mechanisms contribute to insulin release above the physiological glucose range. Among these, different sources of amplification, e.g., hormonal, neuronal, and metabolic, could also contribute to the elevated average $\left[\mathrm{Ca}^{2+}\right]_{\mathrm{IC}}$ driving increased insulin release in both uncoupled $(85)$ and coupled beta cells $(7,70,74)$. The most emphasized mechanism demonstrated already decades ago operates by changing the time that the cells spend in an active state during the plateau phase, by increasing either the frequency or the duration of membrane potential bursts. To the best of our knowledge, there are only a handful of studies that analyzed the glucose-dependence of active time in isolated islets $(7,37,38,76,95,104)$. All of these studies employed membrane potential measurements, which are inherently limited by a rather low number of successful impalements. Additionally, they usually predict that the electrical behavior in other cells is the same as in the observed cells and are therefore unable to quantify the heterogeneity of responses during activation and deactivation and compare it with the behavior during the plateau phase. The same holds true for complex network analyses of functional connectivity that require recordings from many cells at a time $(66,78,79,84,101,123,140)$. Finally and most importantly, at least to some extent all of the studies employed sequential increasing or lowering of glucose during prolonged impalements and then analyzed short intervals in a given concentration. In such experimental setups, the effects of time per se or so-called memory effects cannot be separated from effects of different concentrations of glucose. In our present study, we tried to circumvent all of the above shortcomings.

It should be pointed out that the increase in $\left[\mathrm{Ca}^{2+}\right]_{\mathrm{IC}}$ probably exerts its main effect through increasing the number of fusion events of insulin-containing granules $(97,132)$. Recent mathematical modeling of experimental data corroborates this idea, demonstrating that both mobilization and priming of insulin granules are the main factors determining concentrationdependent insulin secretion $(111,138)$. In theory, the effects observed at supraphysiological glucose concentrations could also be due to mechanisms that do not operate at lower glucose concentrations. It is important to emphasize that although the physiological range of glucose in mice has been known for decades, most experiments are still performed at supraphysiological values, typically above $10 \mathrm{mM}(86,90,102)$.

For beta cells to exert the coordinated function, a high level of cell-cell interactions within islets seem to be of utmost importance $(53,56,71,77,83,120,141,145,147)$. Within areas 
of plasma membrane delimited by tight junctions, beta cells express gap junctions consisting of the connexin 36 protein that allows for electrical coupling and exchange of small signaling molecules between adjacent cells $(35,36,103,105,131)$. Gap junctions, along with other intercellular signaling mechanisms, are thought to ensure coordinated cellular activity, narrowing the range of glucose concentrations stimulating insulin secretion at elevated glucose levels and preventing secretion in low glucose $(18,20,28,88,133)$. However, the functional beta cell networks extracted from $\left[\mathrm{Ca}^{2+}\right]_{1 \mathrm{C}}$ dynamics are much more heterogeneous than one would expect from a syncytium mediated by only gap junctions (14, 30, 34, 140). More specifically, instead of being relatively regular and lattice-like, the functional beta cell networks exhibit a heavy-tailed distribution, small-worldness, and a clustered structure with well-pronounced functional subcompartments $(66,84,101,106,140)$.

As far as we know, the interplay between the abovementioned network parameters and characteristics of beta cell glucose responses is mostly unexplored, even more so when it comes to glucose-dependence of these relationships. Although the role of intercellular communication in islet dysfunction is incompletely understood, more and more studies suggest that the coordinated activity within islets is vital for normal insulin secretion dynamics and may be directly involved in glucose intolerance and the pathogenesis of diabetes mellitus $(39,78,131,141)$. Disruptions in gap junctional and paracrine communication abolish synchronized electrical and $\left[\mathrm{Ca}^{2+}\right]_{\mathrm{Ic}}$ activity and lead to altered plasma insulin oscillations and to glucose intolerance $(71,116)$, as observed in different obesity and diabetes mellitus models $(3,18,31,43,52,53,78,137)$.

This study aimed to systematically measure and analyze, with high spatiotemporal resolution and over long periods of time, the dynamics of $\left[\mathrm{Ca}^{2+}\right]_{\mathrm{I}}$ oscillations in many beta cells at a time with single-cell resolution in acute pancreas tissue slices to assess different glucosedependent properties, with a particular emphasis on emergent collective operations in both physiological and supraphysiological glucose concentrations and their relationship with classical physiological properties. For this, we recorded beta cell activation, activity during the plateau phase, and deactivation, extracted and analyzed both classical and network functional parameters, and finally explored the relations between them. The latter is crucial for a deeper understanding of various aspects of recently reported heterogeneity within islets $(8,21,55$, $119,122,128,129,131)$.

\section{Materials and Methods}

\subsection{Ethics statement}

We conducted the study in strict accordance with all national and European recommendations on care and handling experimental animals, and all efforts were made to minimize the suffering of animals. The Administration of the Republic of Slovenia for Food Safety, Veterinary and Plant Protection approved the experimental protocol (permit number: U3440112/2015/3). 


\subsection{Tissue slice preparation and dye loading}

8-20 week old NMRI mice of either sex were kept on a 12:12 hours light: dark schedule in individually ventilated cages (Allentown LLC, USA) and used to prepare acute pancreas tissue slices, as described previously $(136,139)$. In brief, after sacrificing the mice, we accessed the abdominal cavity via laparotomy. We distally clamped the common bile duct at the major duodenal papilla. Proximally, we injected the low-melting-point $1.9 \%$ agarose (Lonza, USA) dissolved in extracellular solution (ECS, consisting of (in $\mathrm{mM}$ ) $125 \mathrm{NaCl}, 26 \mathrm{NaHCO}_{3}, 6$ glucose, 6 lactic acid, 3 myo-inositol, $2.5 \mathrm{KCl}, 2$ Na-pyruvate, $2 \mathrm{CaCl}_{2}, 1.25 \mathrm{NaH}_{2} \mathrm{PO}_{4}, 1 \mathrm{MgCl}_{2}, 0.5$ ascorbic acid) at $40{ }^{\circ} \mathrm{C}$ into the common bile duct. Immediately after injection, we cooled the agarose infused pancreas with ice-cold ECS and extracted it. We prepared tissue slices with a thickness of $140 \mu \mathrm{m}$ with a vibratome (VT $1000 \mathrm{~S}$, Leica) and collected them in HEPES-buffered saline at RT (HBS, consisting of (in $\mathrm{mM}$ ) $150 \mathrm{NaCl}, 10$ HEPES, 6 glucose, $5 \mathrm{KCl}, 2 \mathrm{CaCl}_{2}, 1 \mathrm{MgCl}_{2}$; titrated to $\mathrm{pH}=7.4$ using $1 \mathrm{M} \mathrm{NaOH}$ ). For staining, we incubated the slices for 50 minutes at RT in the dye-loading solution (6 $\mu \mathrm{M}$ Oregon Green 488 BAPTA-1 AM (OGB-1, Invitrogen), 0.03\% Pluronic F-127 (w/v), and 0.12\% dimethylsulphoxide ( $\mathrm{v} / \mathrm{v}$ ) dissolved in HBS). All chemicals were obtained from Sigma-Aldrich (St. Louis, Missouri, USA) unless otherwise specified.

\subsection{Stimulation protocol and $\left[\mathrm{Ca}^{2+}\right]_{\mathrm{IC}}$ imaging}

We transferred individual tissue slices to a perifusion system containing $6 \mathrm{mM}$ glucose in carbogenated ECS at $37{ }^{\circ} \mathrm{C}$. We exposed them to a single square pulse-like stimulation per slice, with the following glucose concentration (in $\mathrm{mM}$ )/duration of stimulation (in minutes): $7 / 40,8 / 30,9 / 20,12 / 15$, or $16 / 15$, followed by incubation in a solution with substimulatory 6 $\mathrm{mM}$ glucose concentration until all the activity switched off. We used concentrations typically encountered in normal mice in vivo $(7,8$, and $9 \mathrm{mM})$ and two concentrations (12 and $16 \mathrm{mM})$ that lie within the range usually encountered in diabetic mice and are close to values typically used in previous studies (11.1 and $16.7 \mathrm{mM}$, corresponding to 200 and $300 \mathrm{mg} / \mathrm{dl}$, respectively). The concentrations lie closer together near the threshold and further apart in the higher range for a good trade-off between resolution and range. Importantly, each islet was stimulated with a single stimulatory condition. A single stimulation pulse duration varied due to large differences in time needed to activate and deactivate beta cell networks at different glucose concentrations and to ensure a comparable number of $\left[\mathrm{Ca}^{2+}\right]_{\mathrm{Ic}}$ oscillations that entered analyses from different glucose concentrations. To limit the required experiments and analyses to a practically manageable number, the relationships between classical and network parameters were analyzed for the $8 \mathrm{mM}$ and $12 \mathrm{mM}$ glucose protocols only. We performed the imaging on a Leica TCS SP5 AOBS Tandem II upright confocal system (20x HCX APO L water immersion objective, NA 1.0) and a Leica TCS SP5 DMI6000 CS inverted confocal system (20X HC PL APO water/oil immersion objective, NA 0.7). Acquisition frequency was initially set to $1-2 \mathrm{~Hz}$ at $512 \times 512$ pixels during the first phase response, allowing for the determination of response onsets and deactivation, and switched to $27-50 \mathrm{~Hz}$ at $128 \times 128$ pixels for an intermittent sampling of the plateau phase to allow for a more precise quantification of $\left[\mathrm{Ca}^{2+}\right]_{\mathrm{IC}}$ oscillations. Alternatively, a resolution of $10 \mathrm{~Hz}$ at $512 \times 512$ pixels was maintained throughout the whole stimulation protocol. OGB-1 was excited by a $488 \mathrm{~nm}$ 
argon laser, and the emitted fluorescence was detected by Leica HyD hybrid detector in the range of 500-700 nm (all from Leica Microsystems, Germany), as described previously (139).

\subsection{Data analyses}

We manually selected ROIs and exported traces for an off-line analysis utilizing a custom-made software application (ImageFiltering, copyright Denis Špelič). We excluded recordings with extensive motion artifacts. Further off-line analysis of $\left[\mathrm{Ca}^{2+}\right]_{I C}$ traces were made using inhouse MATLAB/Python scripts. Fluorescence signals were expressed as $F / F_{0}$, the ratio of the fluorescence signal $(F)$ at a particular time point of the experiment relative to the initial fluorescence $\left(F_{0}\right)$. To account for photobleaching, we used a combination of linear and exponential fitting. The methodology used to determine $\left[\mathrm{Ca}^{2+}\right]_{\mathrm{IC}}$ signal characteristics, e.g., the duration of oscillations established at a half-maximal amplitude of the spike, the number of oscillations per minute, and the percentage of active time, is described in detail in the respective figures and figure captions. The activation times and deactivation times, i.e., the start of $\left[\mathrm{Ca}^{2+}\right]_{\mathrm{IC}}$ increases/decreases after switching from basal to stimulatory concentration (and vice versa), were selected manually. We considered two cells to be in the same activation/deactivation cluster if their activation/deactivation times were less than 3 seconds apart. For the statistical analyses, we used SigmaPlot 11 and 14 (Systat Software Inc). Statistical differences between groups were tested using ANOVA on Ranks and posthoc Dunn's method. Asterisks denote statistically significant differences $\left(* p<0.05,{ }^{*} p<0.01, * * * p<\right.$ $0.001)$.

\subsection{Network analyses}

To quantify the beta cell collective activity in each islet, we constructed functional connectivity networks. We considered two cells functionally connected if their activity profiles exceeded a preset degree of synchronization, as described elsewhere $(66,78,140)$. The resulting functional networks were diagnosed with conventional network metrics. Specifically, we calculated the average degree and the relative degree distribution to explore the connectivity of cells. To evaluate the network's traffic capacity and functional integration of individual cells, we computed the global efficiency and the largest component. To characterize the functional segregation, we calculated the clustering coefficient and modularity, which reflect the level of clique-like structures within interconnected cell assemblies and the extent of division into smaller subpopulations, respectively. For details, see $(27,65)$.

\subsection{Comparing classical and network parameters}

We examined whether there are any interrelations between different network parameters and classical physiological parameters extracted from the phases of activation, sustained activity, and deactivation. To that purpose, we divided the cells in each islet into three subgroups. One-sixth of the cells with the lowest and highest values were designated to the first and third group, respectively, and the remaining $2 / 3$ of the cells with intermediate values to the second group. The cellular signaling characteristics that we compared were the response onsets in the activation phase, relative active time and node degree in the plateau 
phase, and cellular deactivation times after cessation of stimulation in the deactivation phase. To ensure direct comparability and pooling of the data from all islets, the active times and node degrees were normalized by dividing each value by the average value in the given islet. For example, if a cell had a normalized active time 1.05 and normalized node degree 0.9 , its activity was $5 \%$ higher than the average, whereas the number of connections was $10 \%$ lower. For the activation and deactivation sequence, we used relative ranks. For the first and last responding cell, the activation and deactivation ranks were 0 and 1 , respectively, irrespective of the number of cells or the absolute values of time in the given islet. We performed a separate analysis for islets stimulated with $8 \mathrm{mM}$ and $12 \mathrm{mM}$ glucose.

\section{Results}

The response of a typical beta cell consisted of three subsequent phases, i.e., activation, plateau, and deactivation. Below, we present their physiological and network properties in this logical order.

\subsection{Glucose-dependence of beta cell activation}

Beta cells responded to a given glucose concentration with a delay in the onset of $\left[\mathrm{Ca}^{2+}\right]_{\mathrm{IC}}$ increase (activation delay) that progressively shortened with increasing glucose concentrations (Figure 1, red). Strikingly, the median beta cell activation delay was more than $12 \mathrm{~min}(728 \mathrm{~s})$ at the threshold concentration of $7 \mathrm{mM}$ glucose and progressively decreased to about $1.5 \mathrm{~min}$ (104 s) at $16 \mathrm{mM}$ glucose (Figure 1C). We observed a large degree of heterogeneity in delays among individual cells and cell clusters at a given glucose concentration. Interestingly, this heterogeneity was glucose-dependent, as evident from progressively shorter lags between the first-responding cell's response in a given islet and any other cell's response in this same islet (first cell-any cell delay; Figure 1, blue). More specifically, the interquartile range in first cell-any cell delays decreased from around 12 minutes (728 s) in $7 \mathrm{mM}$ glucose to less than half a minute $(17 \mathrm{~s})$ in $16 \mathrm{mM}$ glucose (Figure 1D). Consistent with the above findings, the time when $50 \%$ of cells activated decreased progressively with increasing glucose concentrations (from $450 \mathrm{~s}$ at $7 \mathrm{mM}$ to $17 \mathrm{~s}$ at $16 \mathrm{mM}$, Figure 1E). 
A
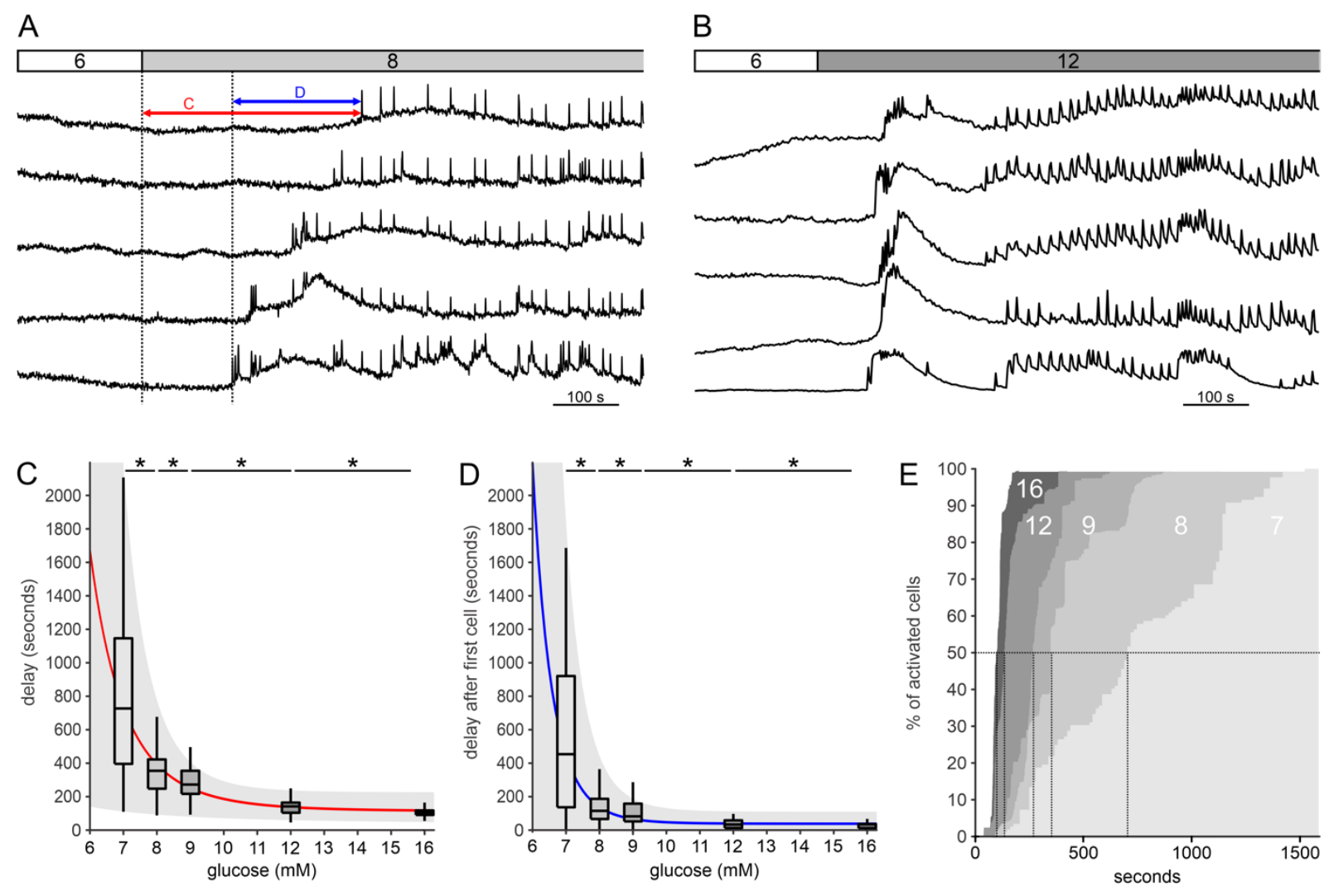

Figure 1: Glucose-dependent activation. A-B Response onsets of typical beta cells to stimulation with $8 \mathrm{mM}(A)$ and $12 \mathrm{mM}$ glucose (B). Lines indicate activation delays in individual cells (red line, pooled data shown in panel C) and variability of delays (blue line, pooled data shown in panel D). C Glucose-dependence of activation delays after stimulation with $7 \mathrm{mM}, 8$ $\mathrm{mM}, 9 \mathrm{mM}, 12 \mathrm{mM}$, and $16 \mathrm{mM}$ glucose. A power-law fit through median values (red line) and the inter-whiskers interval (gray area) are added for better visualization. $1^{\text {st }}$ quartile/median/3rd quartile (Q1/M/Q3), in seconds): 396/728/1148 (7 mM), 248/355/423 (8 mM), $217 / 273 / 355$ (9 mM), 104/142/168 (12 mM), and 91/105/121 (16 mM). D Glucosedependence of first cell-any cell delays. Q1/M/Q3 (in seconds): 130/542/920 (7 mM), 62/112/184 (8 mM), 48/79/155 (9 mM), 10/26/50 (12 mM), and 7/17/33 (16 mM). E Cumulative distributions of activation delays within islets. Vertical lines indicate the time at which half of the cells were activated at a given stimulus (in seconds): 450 (7 mM), 111(8 mM), 78 (9 mM), 25 (12 mM), and $17(16 \mathrm{mM})$. Slopes of sigmoidal dose-reponse fit: 0,002 (7 mM), $0,004(8 \mathrm{mM}), 0,007(9 \mathrm{mM}), 0,017(12 \mathrm{mM})$, and 0,023 (16 $\mathrm{mM})$. Data pooled from the following number of cells/islets: $137 / 7$ (7 mM), 410/10 (8 mM), 378/6 (9 mM), 371/12 (12 $m M), 498 / 7(16 m M)$.

As observed from Figure 1E, the activation of beta cells during stimulation had a staircase-like appearance, suggesting that at least at the temporal resolution used in this study, groups of beta cells, rather than single cells, activated at the same time. Closer inspection of this pattern in the recorded time series revealed that beta cells formed spatiotemporal clusters of neighboring cells in response to glucose stimulation (Figure 2). To quantify the relationship of cluster sizes to glucose concentration, we calculated the percentage of arbitrarily defined 
large clusters (> $33 \%,>50 \%$, and $>67 \%$ with respect to all cells in the islet) for different glucose concentrations (Figure $2 \mathrm{E}$ ). The clusters of activated cells were larger in higher glucose concentrations, as demonstrated by the cluster sizes' cumulative distribution for different glucose concentrations (Figure 2F).
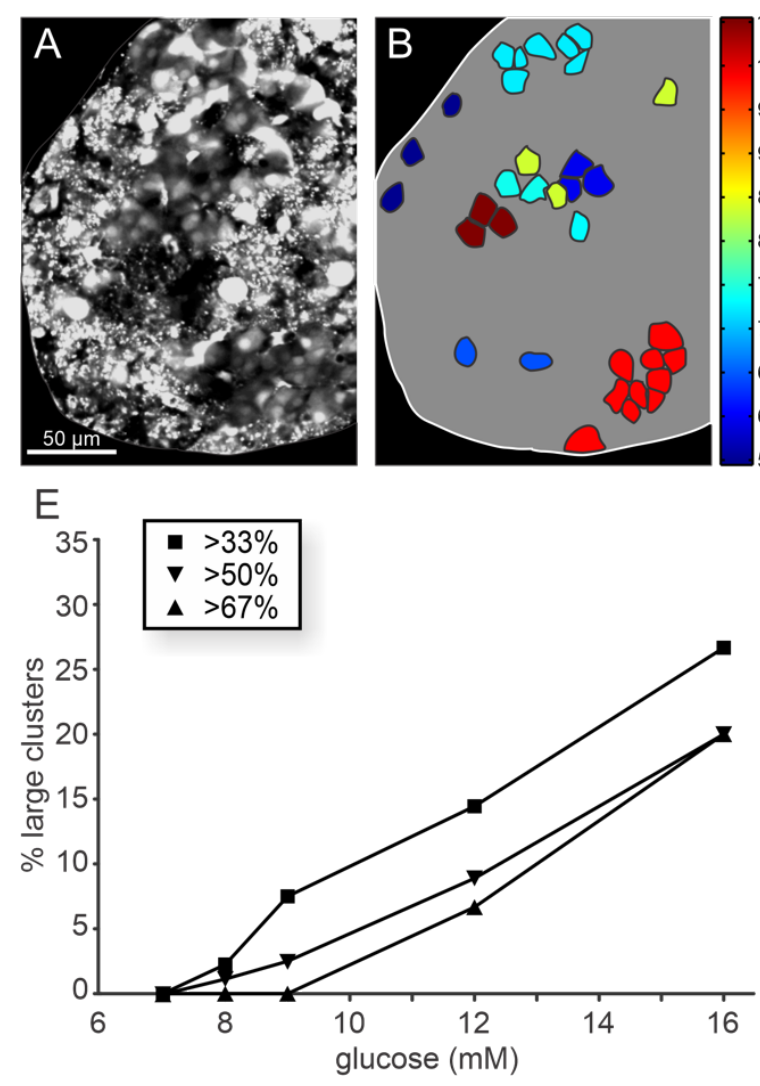
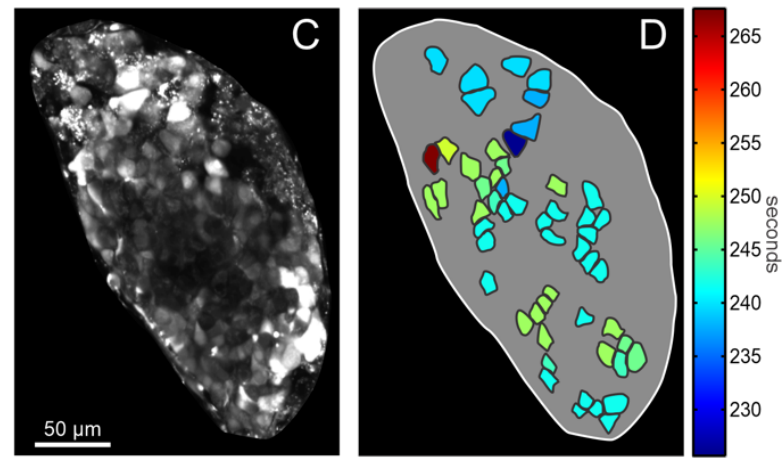

$\mathrm{F}$

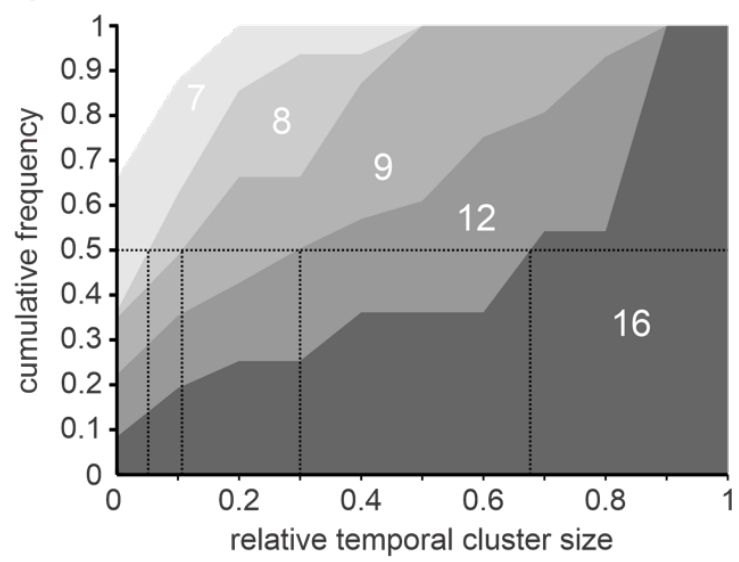

Figure 2: Spatiotemporal characterization of beta cell activation: A-D Color-coded response onset times of beta cells after $8 \mathrm{mM}(B)$ and $12 \mathrm{mM}(D)$ glucose stimulation. A and $C$ show OGB-1 loaded cells in an islet. E: Distribution of relative sizes of clusters (relative to all active cells), signifying simultaneously activated cells under stimulation with different glucose concentrations. F Cumulative distribution of the relative cluster sizes for different glucose concentrations. Vertical lines indicate the relative temporal cluster size during activation of the first half of the cells in an islet: $0(7 \mathrm{mM}), 0.05(8 \mathrm{mM}), 0.11(9 \mathrm{mM}), 0.30(12 \mathrm{mM})$, and 0.68 (16 mM).

\subsection{Glucose-dependent spatiotemporal $\left[\mathrm{Ca}^{2+}\right]_{I C}$ dynamics during the plateau phase}

\subsubsection{Classical functional parameters}

Following activation, the plateau phase was characterized by relatively regular fast $\left[\mathrm{Ca}^{2+}\right]_{\mathrm{IC}}$ oscillations that, especially at higher stimulation levels, encompassed most cells in an islet. Increasing glucose concentrations characteristically affected both the frequency and duration of oscillations (Figure 3). More specifically, the frequency of oscillations increased across the physiological range of glucose concentrations (7-9 mM, Figure $3 \mathrm{~A}$ ), reached its peak at $12 \mathrm{mM}$, 
and decreased to $16 \mathrm{mM}$ glucose (Figure $3 \mathrm{C}$ ). On the other hand, oscillation durations did not seem to be modulated at physiological glucose concentrations but progressively increased in 12 and $16 \mathrm{mM}$ glucose (Figure 3D). As a consequence, the relative active time, i.e., the percentage of time that cells spend at an increased $\left[\mathrm{Ca}^{2+}\right]_{\mathrm{IC}}$, was dominated by the increasing frequency of oscillations in the range from 7 to $9 \mathrm{mM}$ glucose, and by increasing duration of $\left[\mathrm{Ca}^{2+}\right]_{\mathrm{IC}}$ oscillations in higher concentrations. This resulted in a strikingly linear concentrationdependence of active time in the range between 7 and $16 \mathrm{mM}$ glucose (Figure 3E), with the slope of the linear fit, $k=0.043 / \mathrm{mM}$. This slope indicates that the active time increased by roughly $5 \%$ for each $1 \mathrm{mM}$ increment in glucose, starting from substimulatory $6 \mathrm{mM}(A T=0)$, and achieved (by extrapolation) $100 \%$ at $23 \mathrm{mM}$ glucose. As explained further in Discussion, the fit is expected to become non-linear at higher glucose, as also suggested by previous studies, the abovementioned concentration at $100 \%$ of active time is thus probably an underestimation (i.e., the sensitivity is overerstimated). As presented in boxplots, we noticed a great variability of both oscillation durations and frequencies at each glucose concentration. Notably, across different islets within each glucose concentration, there was a clear tendency of $\left[\mathrm{Ca}^{2+}\right]_{I C}$ oscillations to last longer when their frequency was less and vice versa. Therefore, in Figure 3F, we provide an additional presentation of how active time depends on concentration, offering an even further insight into beta cells' coding. More specifically, plotting the average oscillation duration as a function of the average inter-spike interval enables one to simultaneously represent three key parameters graphically: the frequency (i.e., the inverse value of the inter-spike interval), the duration, and the active time, represented here as the correlation slope of the two parameters, reflecting the ratio between duration and inter-oscillation interval of the given oscillation (in the given islet). This approach corroborates the finding that the active time is strongly concentration-dependent, since the slope (active time) increases with increasing glucose. At the same time, it quantitatively confirms the strong inverse relationship between duration and frequency observed across different islets at a given glucose concentration. 

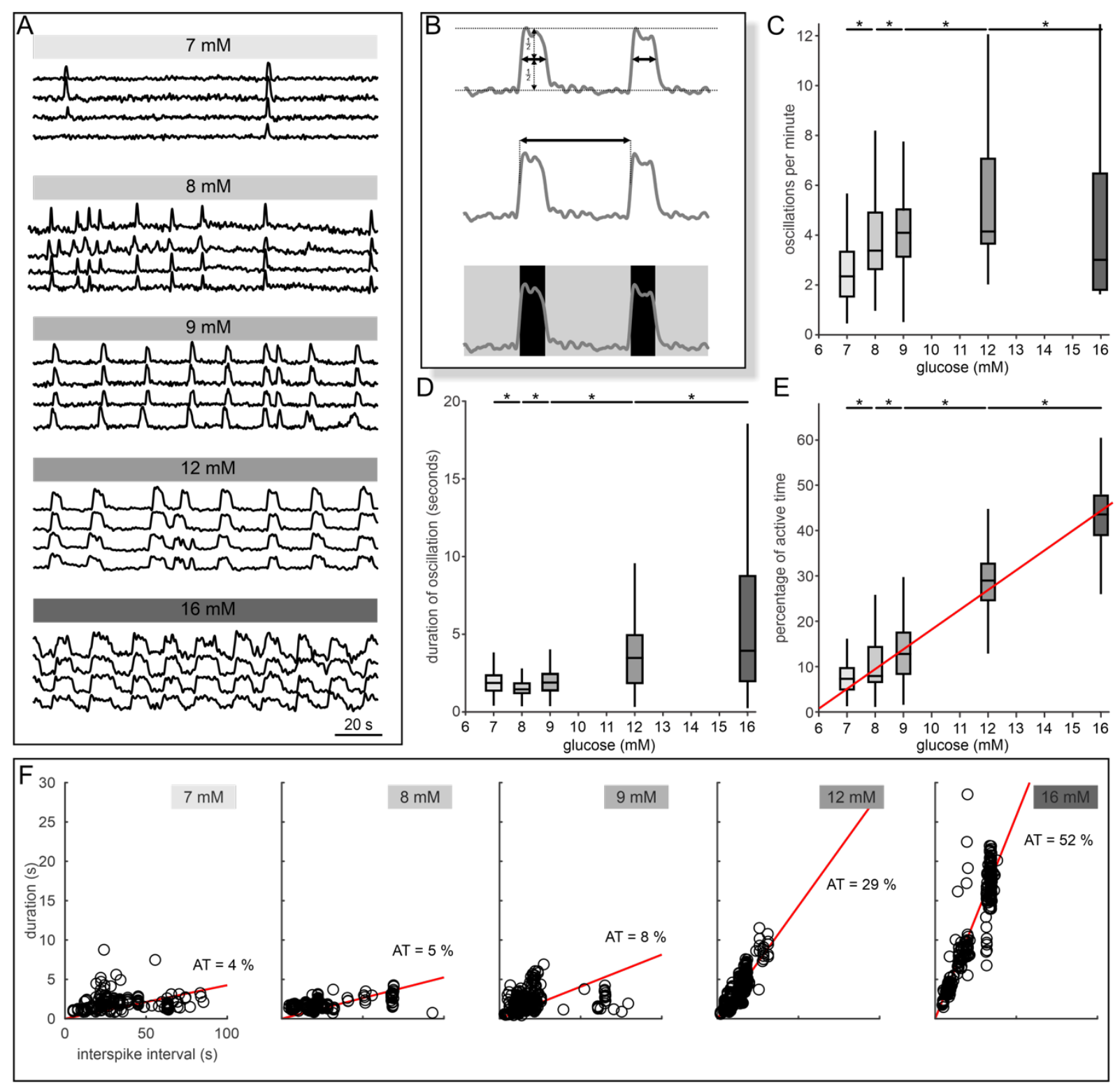

Figure 3: Spatiotemporal characterization of the plateau phase. A The oscillatory $\left[\mathrm{Ca}^{2+}\right]_{\mathrm{IC}}$ activity during stimulation with $7 \mathrm{mM}, 8 \mathrm{mM}, 9 \mathrm{mM}, 12 \mathrm{mM}$, and $16 \mathrm{mM}$ glucose. Shown are four representative cells from an islet per stimulus. B Schematic presentation of analyzed parameters: duration of oscillations at half-maximal amplitude (upper panel), number of oscillations per minute (middle panel), and percentage of active time (lower panel). $C$ Frequency of oscillations. Q1/M/Q3 (in minute ${ }^{-1}$ ): 1,5/2,4/3,3 (7 mM), 2,6/3,4/4,9 (8 mM), 3,1/4,1/5,0 (9 mM), 3,7/4,2/7,1 (12 mM), and 1,8/3,0/6,5 (16 mM). D Duration of oscillations. Q1/M/Q3 (in seconds): 1,4/1,8/2,4 (7 mM), 1,2/1,5/1,9 (8 mM), 1,4/1,9/2,4 (9 mM), 1,9/3,5/4,9 (12 mM), and 2,0/3,9/8,7 (16 mM). E Percentage of active time. Q1/M/Q3 (in \%): 5/7/9 (7 mM), 7/8/14 (8 mM), 8/13/18 (9 mM), 25/29/33 (12 mM), and 39/44/48 (16 mM). The red line indicates a linear fit through medians $\left(R^{2}=0.99\right)$. $F$ Durations of individual oscillations as a function of the respective interspike interval. Glucose concentrations and slopes (designated as active time, AT) of linear regression lines are indicated. Data pooled from the following number of cells/islets: 171/8 (7mM), 241/7 (8 mM), 350/16 (9 mM), 392/16 (12 $m M)$, and 281/6 (16 $\mathrm{mM})$. 


\subsubsection{Network functional parameters}

To further characterize beta cell collective behavior during the plateau phase, functional networks were constructed for each glucose concentration, as described in the Methods section. The results are presented in Figure 4. As shown previously, functional connectivity within an islet evolved with increasing stimulatory glucose concentrations (101). Stimulation with low glucose concentrations ( 7 or $8 \mathrm{mM}$ ) yielded mostly isolated and seldom synchronized beta cell activity. Increasing glucose resulted in greater coordination of cellular activity within an islet, demonstrated by the increasing density of networks (Figure 4A-E), greater average correlation in activity, and higher node degrees (Figure $4 G$ and $H$ ). The increase in synchronization can be explained by increased activity, i.e., a greater number of $\left[\mathrm{Ca}^{2+}\right]_{\mathrm{IC}}$ oscillations and an increased number of cells involved in individual oscillations. The relative degree distributions for different glucose concentrations presented in Figure 4F show that beta cell networks are, in general, very heterogeneous. Except for very high glucose concentrations, a relatively small fraction of cells existed, which were very well connected. In 7 and $8 \mathrm{mM}$ glucose, these cells were functionally correlated with up to 20-30\%, whereas in 9 and $12 \mathrm{mM}$ glucose, they were correlated with up to $60 \%$ of other beta cells. At $16 \mathrm{mM}$, the network became very dense, with most of the cells having a high number connections (Figure $4 \mathrm{E}$ and $\mathrm{F}$ ). Intense stimulation diminished the intrinsic cellular variability, and the spatiotemporal activity was dominated by global and fully synchronized $\left[\mathrm{Ca}^{2+}\right]_{\mid \mathrm{C}}$ oscillations. Increasing glucose concentrations also resulted in functional networks that were more integrated, both locally, as illustrated by an increase in average clustering (Figure 4J), and globally, as demonstrated by decreased modularity (Figure 4K). Moreover, the rise in glucose concentration led to more robust networks with higher levels of functional integration, as evident from an increase in both the relative largest component and the global efficiency (Figures $4 \mathrm{I}$ and $4 \mathrm{~L}$ ). 


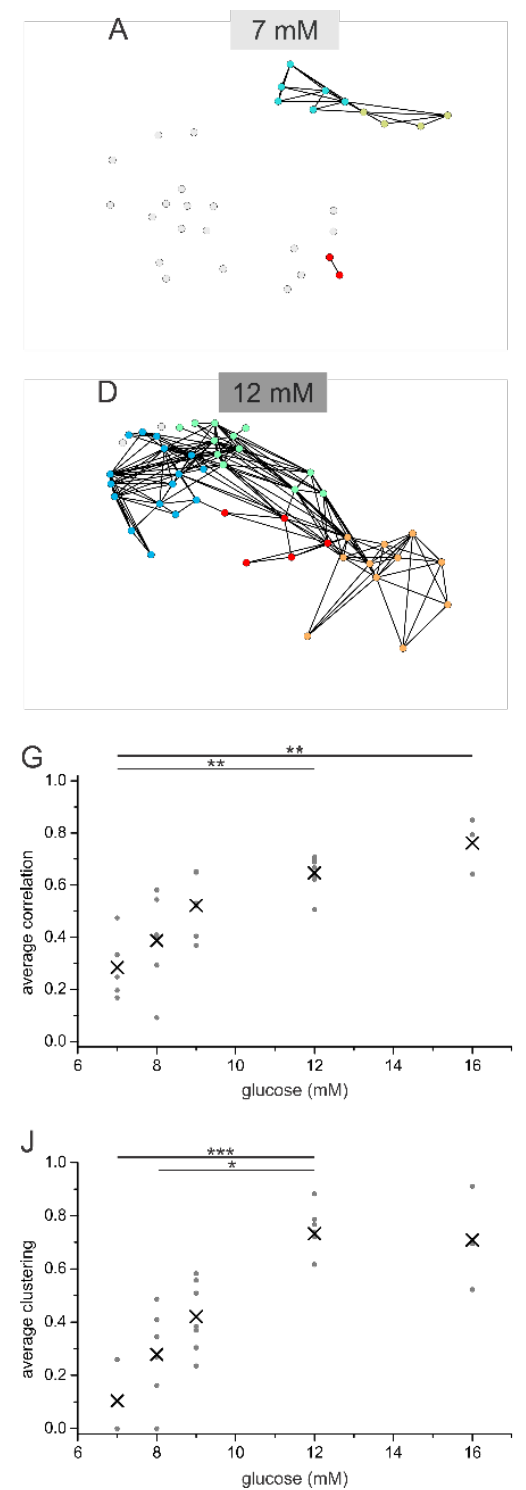

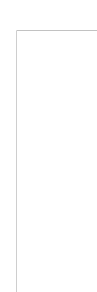

B
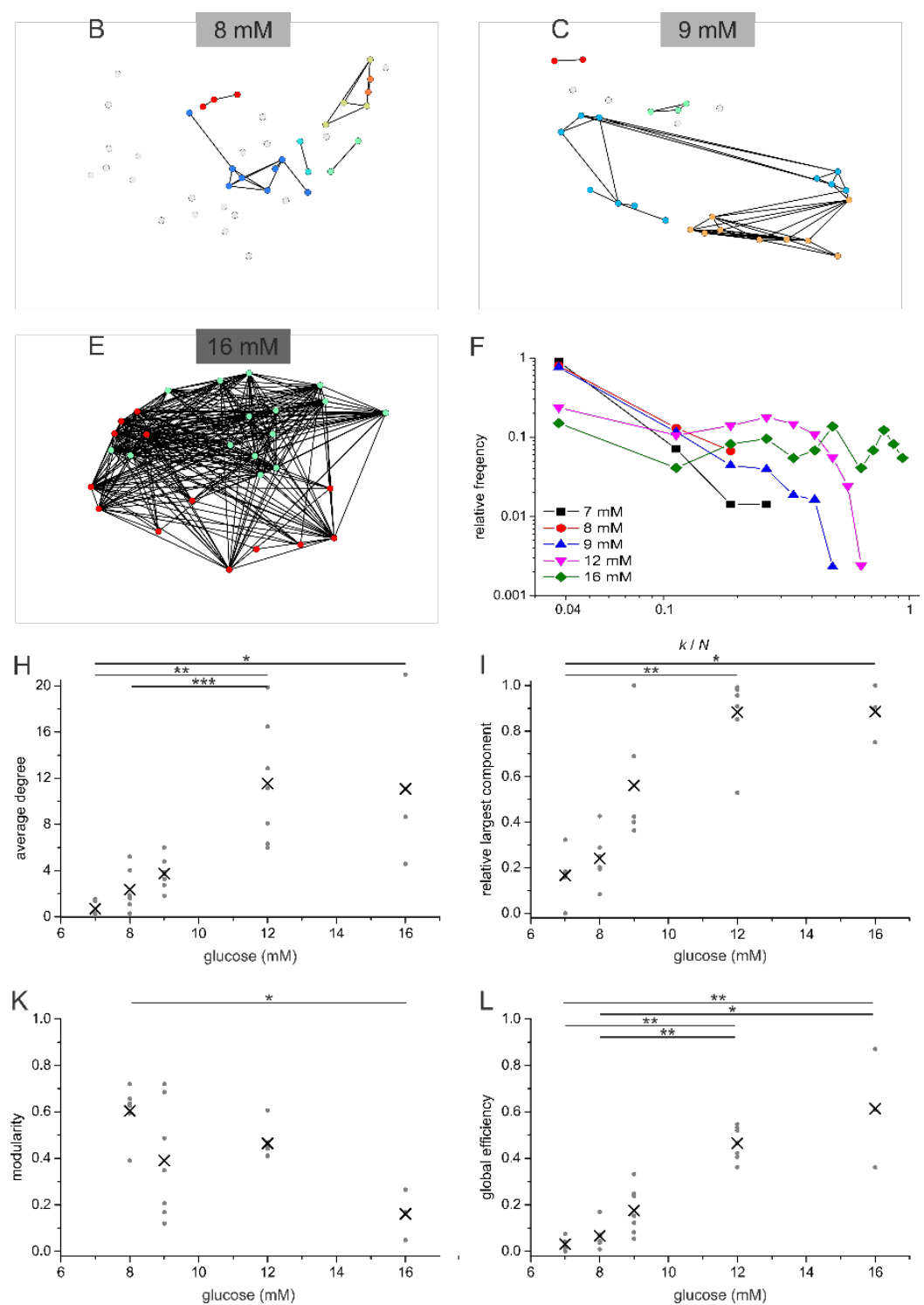

Figure 4: Beta cell functional connectivity at different glucose concentrations. A-E Characteristic functional networks for 7 (A), 8 (B), 9 (C), 12 (D), and $16 \mathrm{mM}$ glucose (E). $\boldsymbol{F}$ Relative degree distributions at different glucose concentrations combined and normalized for all functional networks at a given stimulatory condition; $k$ denotes node degree, and $N$ denotes the number of all cells in a given islet. G-L Synchronization and network metrics as a function of glucose concentration: average correlation coefficient (panel $G$, median (M)/glucose concentration (GC, in $\mathrm{mM}$ ): 0.25/7, 0.41/8,0.52/9,0.66/12, and 0.79/16), average network degree (panel $H, M / G C$ (in $\mathrm{mM}$ ): 0.33/7, 1.74/8, 3.27/9, 12.86/12, and 8.66/16), relative largest component (panel I, M/GC (in $m M$ ): 0.17/7, 0.23/8,0.41/9,0.91/12, and 0.90/16), average clustering coefficient (panel J, M/GC (in $\mathrm{mM}$ ): 0/7, 0.31/8,0.38/9,0.72/12, and $0.70 / 16$ ), modularity (panel $K, M / G C$ (in $m M$ ): $0.25 / 7,0.63 / 8,0.35 / 9,0.44 / 12$, and 0.17/16; note that in $7 \mathrm{mM}$ the networks were too sparse for a firm calculation of the modularity), and global efficiency (panel L, M/GC (in mM): 0.03/7, 0.06/8, 0.12/9, 0.43/12, and 0.61/16). Grey dots indicate values for individual islets and the black crosses the averages over all islets at a given concentration. Data pooled from the following number of cells/islets: 158/5 (7 mM), 343/6 (8 mM), 434/7 (9 mM), 413/9 (12 mM), and 73/3 (16 mM). 


\subsection{Glucose-dependence of beta cell deactivation}

Removal of stimulatory glucose led to a concentration-dependent deactivation of beta cells (Figure 5, red). We observed a clear concentration-dependence for delays before the onset of deactivation (deactivation delay), which were less than 3 min (median delay $174 \mathrm{~s}$ ) at $7 \mathrm{mM}$ glucose. After stimulation by higher glucose concentrations, beta cells remained active longer. This delay reached a maximum value of about $15 \mathrm{~min}$ (median delay $815 \mathrm{~s}$ ) after $16 \mathrm{mM}$ (Figures $5 \mathrm{C}$ and $\mathrm{E}$ ). The differences between cells of the same islet, as judged by first cell-any cell delays, also became larger with higher glucose (Figure 5, blue). However, this trend was less well pronounced than the inverse trend during activation. Additionally, for 7, 8, and $9 \mathrm{mM}$ glucose, the differences between cells of the same islet were smaller during deactivation than during activation, whereas for 12 and especially $16 \mathrm{mM}$ glucose, they became larger (compare first cell-any cell activation and deactivation delays in Figures 1 and 5).

A

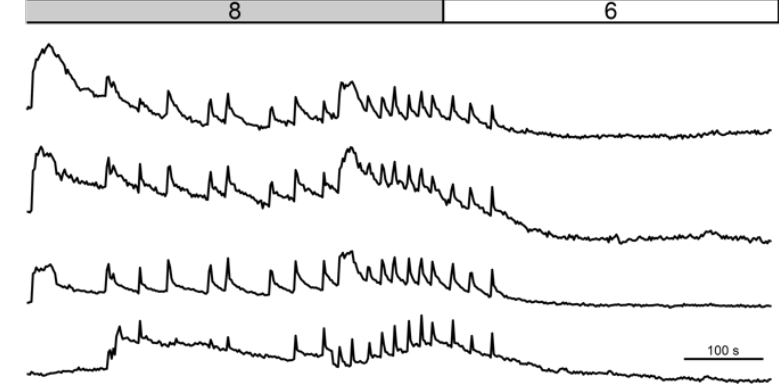

B

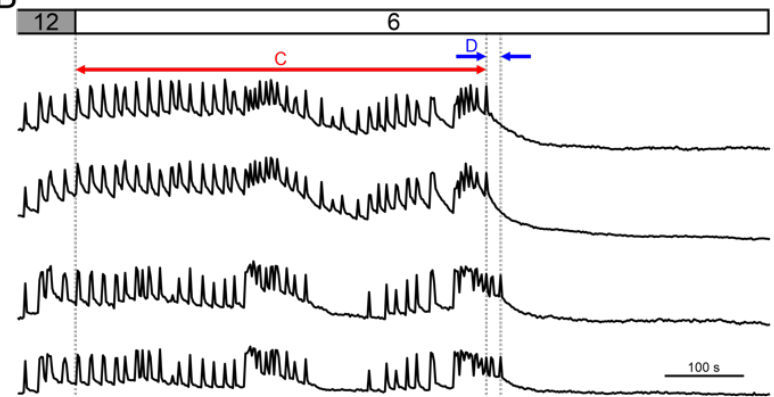

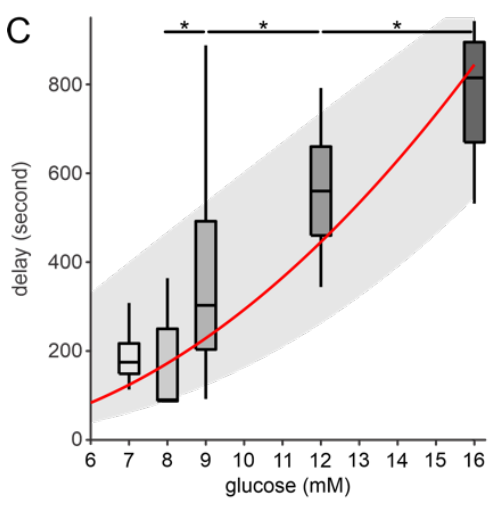
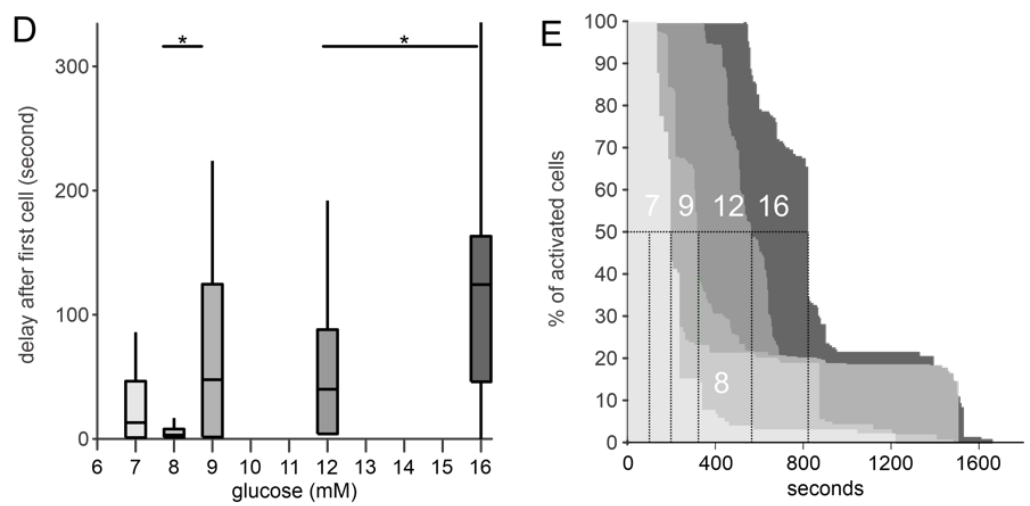

Figure 5: Glucose-dependent deactivation. A-B Deactivation of beta cells after cessation of stimulation with $8 \mathrm{mM}(A)$ and $12 \mathrm{mM}(B)$ glucose. Lines indicate deactivation delays in individual cells (red, pooled data are shown in panel C) and any-cell-first-cell deactivation delays (blue, pooled data shown in panel D). C Deactivation delays after stimulation with 7 $\mathrm{mM}, 8 \mathrm{mM}, 9 \mathrm{mM}, 12 \mathrm{mM}$, and $16 \mathrm{mM}$ glucose. A power-law fit through median values (red line) and through the inter-whisker intervals (gray area) are added for better visualization. Q1/M/Q3: 149/175/217 (7 mM), 87/90/250 (8 mM), 203/303/492 (9 mM), 460/560/660 (12 $\mathrm{mM})$, and 670/815/895 (16 mM). D Glucose-dependence of first cell-any cell deactivation delays. Q1/M/Q3: 1/13/48 (7 mM), 1/3/8 (8 mM), 1/48/125 (9 mM), 4/40/88 (12 mM), and $46 / 124 / 163$ (16 mM). E Cumulative distributions of delays between the end of stimulation and deactivation of any given cell. Vertical lines indicate the time at which half of the cells 
deactivated at a given stimulus (in seconds): 193 (7 mM), 100 (8 mM), 316 (9 mM), 560 (12 $\mathrm{mM})$, and 816 (16 mM). Data pooled from the following number of cells/islets: $107 / 7(7 \mathrm{mM})$, 164/5 (8 mM), 372/6 (9 mM), 366/12 (12 mM), 197/6 (16 mM).

As with activation, deactivation occurred in spatiotemporal clusters (Figure 6), a phenomenon observed at both physiological (Figure 6A-B) and supraphysiological glucose concentrations (Figures 6C-D). The abovementioned increase in intercellular heterogeneity in higher glucose was evident in the decrease in cluster size of cells that deactivated together in higher glucose concentrations. The sizes of these clusters decreased with increasing glucose concentrations (Figures 6E-F). This strongly contrasts with the activation properties where cluster sizes were larger in higher glucose concentrations (compare Figures 2 and 6).

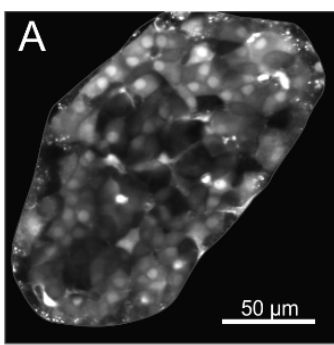

E

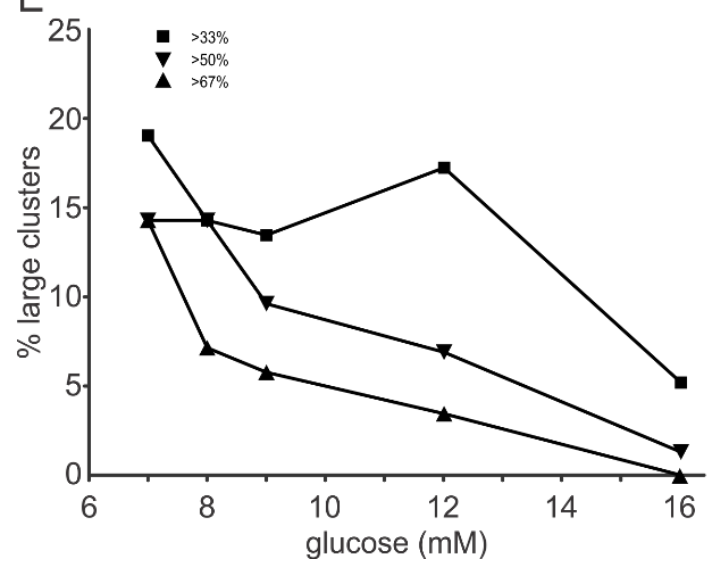

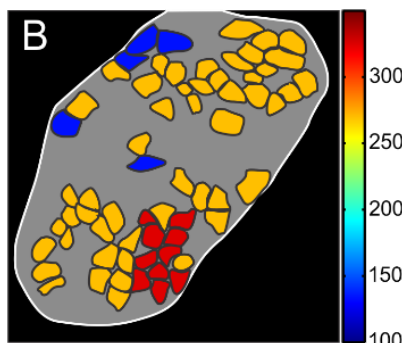

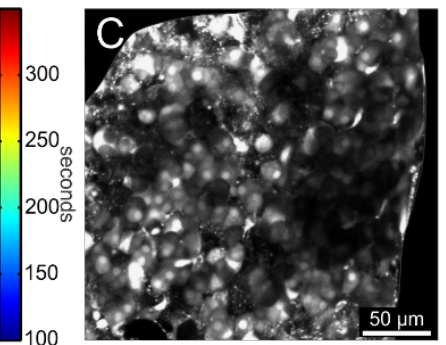

$\mathrm{F}$

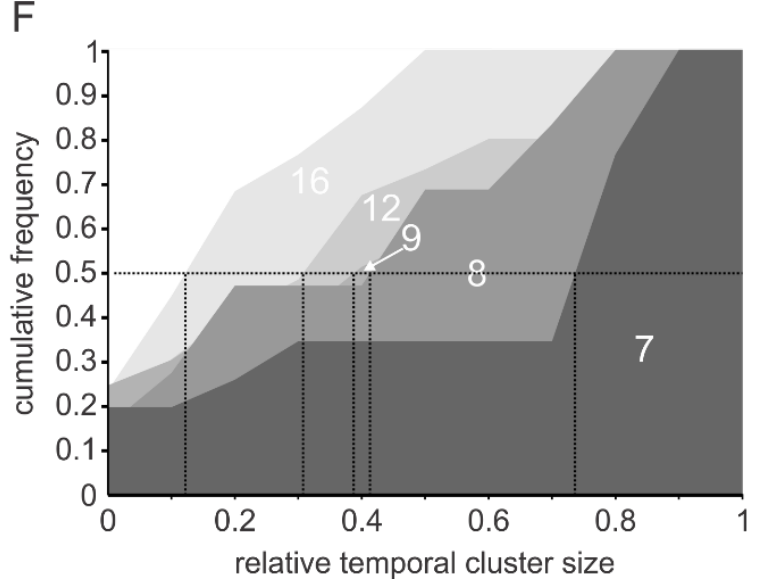

Figure 6: Spatio-temporal characterization of beta cell deactivation. A-D Color-coded response deactivation after cessation of stimulation with $8 \mathrm{mM}(B)$ and $12 \mathrm{mM}(D)$ glucose. $A$ and $C$ show the loading of cells with OGB-1 for respective islets. $E$ Distribution of relative sizes of clusters, signifying simultaneously deactivated cells after removal of stimulus. $\boldsymbol{F}$ Cumulative distribution of relative cluster sizes. Vertical lines indicate the relative temporal cluster size during deactivation of the first half of the beta cells in an islet.

\subsection{Comparison between activation, plateau activity, and deactivation}

We compared the three phases of beta cell response in Figure 7. Figures 7B-D show how the one sixth of cells with shortest delays before activation (i.e., the first-responders) compare with the two third majority of cells with average delays and the one sixth of cells with the longest delays (i.e., the last-responders), with respect to active time and node degree during the plateau phase, as well as the deactivation time rank, for two selected concentrations of glucose, i.e., 8 and $12 \mathrm{mM}$. The first-responders were the most active group in the plateau 
phase in $12 \mathrm{mM}$ glucose and more active than the last responders in $8 \mathrm{mM}$ glucose (Figure 7B). The first-responders also had the most functional connections in $12 \mathrm{mM}$ glucose and more than the last-responders in $8 \mathrm{mM}$ glucose (Figure 7C). Surprisingly, the relation with deactivation seemed to be glucose-dependent, with the first-responders being the last to stop their activity after exposure to $8 \mathrm{mM}$ glucose and the last-reponders being the last to stop their activity after exposure to $12 \mathrm{mM}$ glucose (Figure 7D). The relationship between both parameters calculated during the plateau, i.e., the active time and the node degree is displayed in Figure 7E. The cells with the most functional connections, i.e., hubs, had longer active times than the cells with the least functional connections in $8 \mathrm{mM}$ glucose, whereas there were no significant differences in $12 \mathrm{mM}$ glucose. Furthermore, in both glucose concentrations the cells that deactivated the first (i.e., the first-deactivators) had the shortest active times (Figure 7F). Finally, the first- deactivators had the least functional connections in $8 \mathrm{mM}$ glucose and less connections than the majority in $12 \mathrm{mM}$ glucose (Figure 7G). The remaining 6 pairwise comparisons (i.e., activation time rank, deactivation time rank, and node degree vs. relative active time; activation time rank vs. deactivation time rank; activation time rank and deactivation time rank vs. node degree) are shown in Figure S1) 

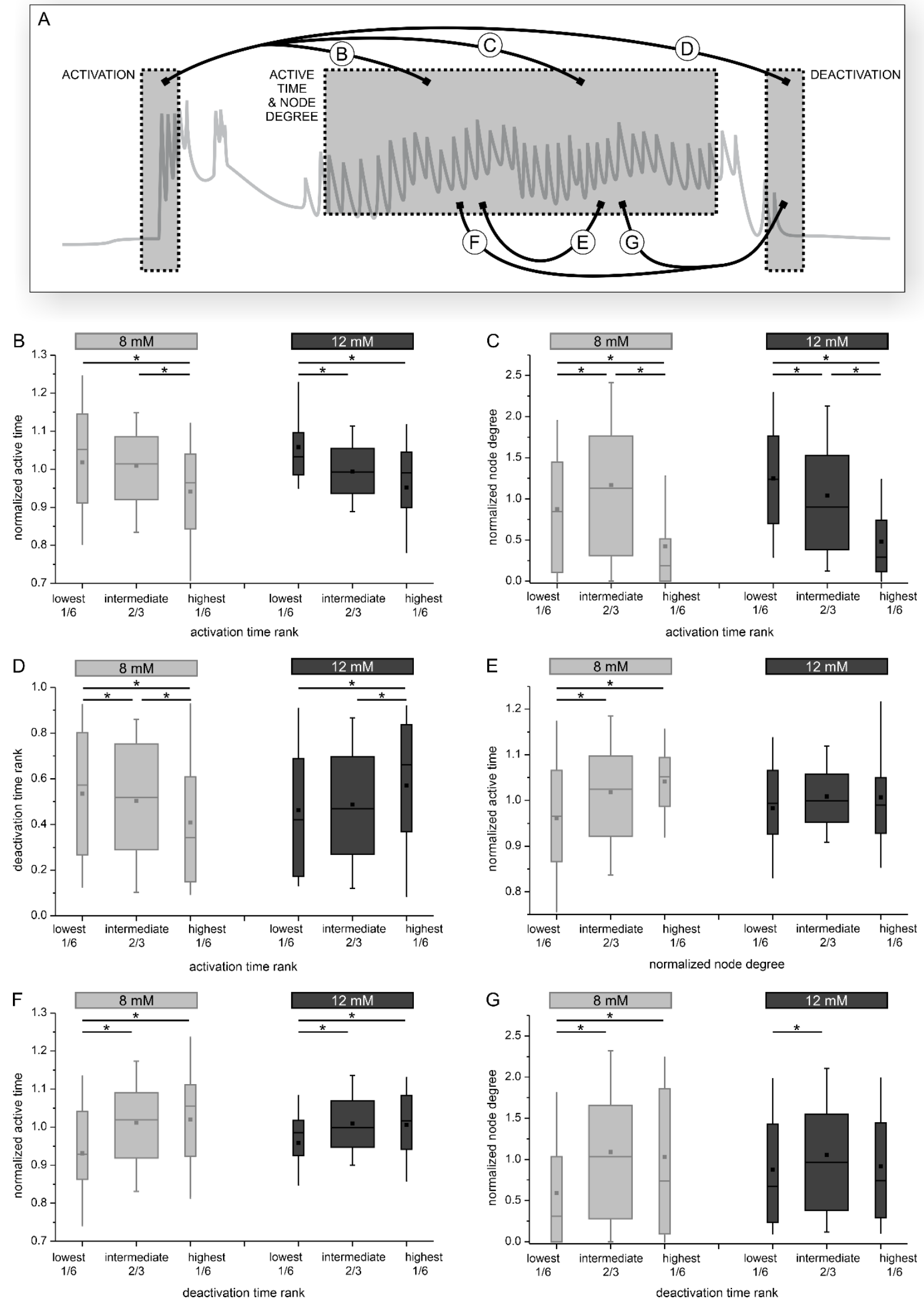

Figure 7: The relationship between functional parameters during activation, plateau activity, and deactivation, in $8 \mathrm{mM}$ (light grey) and $12 \mathrm{mM}$ (dark grey) glucose. A The analyzed parameters with respect to the phases of a typical response. Letters indicate panels 
with pairwise comparisons. B-D The relationship between response onset (activation rank) and the relative active time $(B)$, node degree $(C)$, and deactivation rank (D). $\boldsymbol{E}$ The relationship between node degree and relative active time during the sustained plateau activity. F-G The relationship between deactivation time rank and active time (F), as well as node degree (G). The analysis was performed on a particular set of islets subjected to sustained and long-lasting recordings ( 1 hour). Data pooled from the following number of cells/islets: $587 / 7$ (8 $\mathrm{mM}$ ) and $860 / 9$ (12 mM).

\section{Discussion}

For clarity, we discuss the importance of our findings in the logical order that follows a typical beta cell response to glucose and which was already employed above, i.e., from activation to deactivation.

\subsection{Activation}

We wish to first addres the possibility that the observed behavior, at least during activation and deactivation, is an experimental artifact due to dynamics of glucose increases in our setup in various parts of the islet. However, as we demonstrated before by using a large extracellular dye to quantify perifusion in our chamber, we believe that this is most certainly not the case and that beta cells are quickly exposed to practically identical extracellular glucose concentrations (139). In previous studies, the activation appeared either synchronous among cells (26) or varied to some degree $(44,59,62,78,81,85,99)$. In either case, to the best of our knowledge, this property has not been systematically analyzed nor emphasized, with the exception of our previous reports using in total only two different concentrations of glucose ( 8 and $12 \mathrm{mM})(139,142)$. The present study confirmed our previous findings for these two particular concentrations, using an independent large set of cells and islets from different animals. More importantly, here we employed a whole range of concentrations and beta cell activation profiles exhibited pronounced glucose-dependence and considerable variability in time and space (Figure 1). More specifically, we detected a median response delay of 15 minutes at the threshold of $7 \mathrm{mM}$ glucose, which became progressively shorter and reached a median delay of 2 minutes at the highest tested concentration of $16 \mathrm{mM}$ glucose. We propose this phenomenon be termed "advancement" of beta cell activation. A similar temporal profile of metabolic activity observed after stimulation with different glucose concentrations directly corroborates the advancement observed in this study, suggesting that the time needed for the cells to metabolize enough glucose to become active becomes progressively shorter with increasing stimulus intensity $(48,81)$. Physiologically, an earlier response to a stronger stimulus may play an important role in preventing too large excursions of glucose in vivo. Interestingly, during the first couple of minutes following activation and before a sustained pleateau phase was established, an exceedingly high frequency of fast oscillations or a $\left[\mathrm{Ca}^{2+}\right]_{\mathrm{IC}}$ signal that could be explained by continuous bursting of electrical activity were observed, indicating that during this time, there is a transient "overshoot" of activity, as observed before $(59,91,111,117,139,142)$. Further studies are needed for a more 
detailed quantitative description and to determine the mechanistic substrate of this phenomenon, but from a homeostatic perspective, this behavior could indicate that beta cells behave as both phasic and tonic sensors, responding differently to an increasing and a constantly increased glucose, again ameliorating excursions of glycemia in vivo $(89,98,100$, 107). This is especially important considering that in vivo, $\left[\mathrm{Ca}^{2+}\right]_{\mathrm{IC}}$ may actually follow an oscillatory rather than a sustained profile $(42,67,109)$, that $\left[\mathrm{Ca}^{2+}\right]_{\mathrm{IC}}$ dynamics can largely explain biphasic insulin secretion $(108,111)$, and that the loss of first-phase insulin secretion is an early sign of T2DM $(32,115)$.

Moreover, we demonstrated large heterogeneity between individual cells within the same islet: at the threshold glucose level, the first cells responded after $\sim 3$ minutes, and the last cells more than 25 minutes later. This variability indicates large differences in their sensitivity to glucose. Due to a limited number of concentrations and time periods employed in our study, we cannot exclude the possibility that the actual threshold for activation actually lies a bit below $7 \mathrm{mM}$ glucose, but at least in the NMRI strain and for our study design, cells never exhibited any activity at $6 \mathrm{mM}$ glucose. However, since beta cells may also act as differential and not only difference sensors, we do not exclude the possibility that at least some cells may at least transiently respond to $6 \mathrm{mM}$ glucose, in case they were exposed to lower concentrations before (e.g., $3 \mathrm{mM}$ ) .

From a functional point of view, differences in sensitivity to glucose enable recruitment. Looking at the slope of the cumulative distributions in Figure 1, there was practically no cooperativity during recruitment at $7 \mathrm{mM}$ glucose, strongly suggesting that at this concentration, active cells did not seem to appreciably increase the probability of inactive cells becoming active. In higher glucose concentrations, differences between cells did not just become shorter due to higher glucose and faster responses, but there seemed to be an important contribution of active cells increasing the probability of inactive cells to become active. This is probably a consequence of increasing length constants for the electrotonic spread of gap junctional currents due to increasing input resistance and increasing junctional conductance, of intercellular diffusion of other messengers or intermediates, or a combination of all. This temporal aspect of recruitment is further complemented and the proposed mechanism corroborated by the finding that at the employed temporal resolution, clusters of nearby cells were recruited together and these clusters became larger in higher glucose.

We do not wish to suggest that the first-responders are in any way necessary for islets to respond to glucose and that their role is fixed in time. It is reasonable to speculate that the removal or dysfunction of first-responders would make other cells become first-responders $(49,82,122,128,129)$, and recent experimental data corroborated this (91). Even without removal or dysfunction, the metabolic status and physiological features change as beta cells mature (12). This suggests that a cell's role may also dynamically change with time, possibly within hours. To address this possibility, repetitive stimulations over longer periods are required in the future. Finally, activation seems to be an attractive additional parameter for testing the effects of various drugs, but appropriately long experimental protocols are needed to account for the large heterogeneity between cells, especially if concentrations $<9 \mathrm{mM}$ glucose are used.

\subsection{Plateau activity}




\subsubsection{Fast $\left[\mathrm{Ca}^{2+}\right]_{\mathrm{IC}}$ Oscillations}

A hallmark of the plateau phase during sustained stimulation with glucose are repetitive fast $\left[\mathrm{Ca}^{2+}\right]_{\mathrm{IC}}$ oscillations that correspond to bursts of membrane potential depolarization proximally and pulses of insulin secretion distally in stimulus-secretion coupling cascade (7, $13,19,23,25,59,60,125,139)$. A few studies attempted to decipher how glucose modulates the properties of these fast $\left[\mathrm{Ca}^{2+}\right]_{\mathrm{IC}}$ oscillations, yielding somewhat contradictory results. For instance, a recent microelectrode array study demonstrated that within the physiological concentration range glucose increased only frequency (95). In contrast, sharp electrode and $\left[\mathrm{Ca}^{2+}\right]_{\mathrm{IC}}$ imaging studies showed that supraphysiological concentrations affected mostly oscillation duration, with little effect on the frequency of oscillations $(7,13,76,104)$. On the other hand, Cook's research suggests that frequency is the crucial regulated parameter across a wide range of glucose concentrations $(37,38)$. In the present paper, we found that the doseresponse relationship showed two different regimes (Figure 3). First, the frequency of oscillations followed the increase in glucose concentration within the physiological limits of glucose concentrations,, increasing from approximately $2 / \mathrm{min}$ to $4 / \mathrm{min}$ from 7 to $9 \mathrm{mM}$ glucose, whereas in this range, the oscillation durations did not seem to change to a biologically relevant extent and remained close to 2 seconds long. At higher glucose concentrations, an increase in oscillation duration rather than in frequency became the predominant strategy of increasing activity. From $9 \mathrm{mM}$ to $16 \mathrm{mM}$ glucose, the oscillations increased in duration approximately two-fold, whereas the frequency showed an inverse Ushape behavior, reaching a peak at 9 and $12 \mathrm{mM}$ glucose and decreasing at the highest concentration tested. Although we did not test concentrations beyond $16 \mathrm{mM}$, our findings are consistent with the view that ultimately, fast $\left[\mathrm{Ca}^{2+}\right]_{I C}$ oscillations disappear due to continuous bursting at very high levels of stimulation. As a side note, with current $\left[\mathrm{Ca}^{2+}\right]_{\mathrm{IC}}$ imaging approaches, it is impossible to capture very fast $\left[\mathrm{Ca}^{2+}\right]_{\mathrm{IC}}$ oscillations that correspond to individual action potentials (47).

As a result, there was a strikingly linear increase in the active time over the range of glucose concentrations tested (Figure 3 ), a feature also observed in studies utilizing microdissected islets $(38,76)$. In our hands, a single beta cell spent less than $10 \%$ of the time in an active state at the threshold concentration and the active time increased by approx. $5 \%$ per each $\mathrm{mM}$ of glucose increase. At this rate, the oscillatory behavior would reach a sustained active state (i.e., an active time of $100 \%$ ) at approx. $25 \mathrm{mM}$ glucose or somewhat higher, given that the dose-response curve is probably flatter at higher concentrations (124). This is in good agreement with previous insulin secretion data, as well as $\left[\mathrm{Ca}^{2+}\right]_{I C}$ imaging and electrophysiological studies $(9,20,41,57,74,97)$. A theoretically important aspect of the dual behaviour of the concentration-coding principle is that a beta cell cannot "know" or sense the glucose concentration based on either the frequency or duration of oscillations alone. This is further supported by the finding that at every given glucose concentration, there was a wide range of oscillation durations and frequencies (and a strong inverse relationship between the two). In other words, at a given glucose concentration, some islets responded with longer and less frequent oscillations and others with shorter and more frequent oscillations. Recent research suggests that at least within an islet, a higher intrinsic frequency is observed in metabolically less active cells (146). It remains to be investigated whether islets with higher 
frequencies tend to be less metabolically active compared with other islets. However, the active time or the product of duration and frequency of oscillations, is the physiological parameter that very closely reflects the concentration of glucose which beta cells are exposed to. In turn, the active time is closely related to insulin secretion $(6,13,22,23,61,72,126)$. A practically very important repercussion of the above is that when studying the add-on effects of physiological and pharmacological secretagogues, one should always keep in mind the stimulatory glucose concentration used and not focus on either the frequency or duration of oscillations alone, but always calculate the active time.

The relationship between $\left[\mathrm{Ca}^{2+}\right]_{\mathrm{IC}}$ oscillations and insulin release $(9,20,41,57,74,97)$ has recently been integrated into the so-called metronome model. This model predicts that an increase in glucose increases the active time of bursting electrical acitivity and fast $\left[\mathrm{Ca}^{2+}\right]_{\mathrm{IC}}$ oscillations, leaving the frequency of the underlying slow oscillations unaffected, and ultimately leads to an increase in the amplitude of insulin pulses (127). Importantly, the dynamics of insulin release cannot be entirely explained by membrane potential and $\left[\mathrm{Ca}^{2+}\right]_{1 \mathrm{C}}$ dynamics, but probably also involve changes in mobilization and priming of insulin granules (111).

\subsubsection{Functional networks}

Beta cells within a mouse islet associate into a single large syncytium. More specifically, gap junctional coupling via connexin 36, as well as many additional cell-cell contacts, paracrine, and neuronal signaling mechanisms form the structural basis for complex interactions between cells $(5,45,51,92,121,144)$. These interactions enable beta cells to function more efficiently than a comparable number of dissociated cells, by partially overcoming their heterogeneity (112-114). However, some heterogeneity persists in beta cells in islets and recent research suggests that it plays a crucial role for normal beta cell function $(21,106,118$, 131). One of the important tools to quantify heterogeneity are classical physiological and network analyses of complex spatiotemporal $\left[\mathrm{Ca}^{2+}\right]_{\mathrm{IC}}$ dynamics $(78,140)$, which enable identification of cells that play important roles in an islet's response to secretagogues, e.g., cells that respond first (i.e., first-responders), cells that start the $\left[\mathrm{Ca}^{2+}\right]_{\mathrm{IC}}$ waves that synchronize fast $\left[\mathrm{Ca}^{2+}\right]_{\mathrm{Ic}}$ oscillations (i.e., pacemakers), cells that functionally interact with the most other cells (i.e., hubs), etc $(19,66,78,139,140,143,146)$. These roles are probably crucial for generation of coordinated rhythmic activity $(15,18,36,66,78,84,101,120,123$, $140,142)$ and there is growing evidence that both environmental and genetic factors may target connectivity and heterogeneity in the pathogenesis of diabetes mellitus $(4,53,78,131$, 141, 145).

In the present study, we advanced our understanding of beta cell networks by confirming the glucose dependency of intercellular connectivity and by systematically comparing the obtained network properties with classical physiological characteristics at the level of individual cells. The latter aspect is covered in the last chapter. With respect to the first, we found that the functional networks are segmented, locally clustered, and heterogeneous for physiological glucose concentrations. In other words, from a functional point of view, this might be regarded as a concept of islets within islets. Higher stimulation led to a more synchronized behavior and hence to denser, more integral and efficient networks, functioning 
as a large single network. This importantly corroborates our previous findings, but on a larger dataset, on a wider range of glucose concentrations, and based on a different stimulation paradigm $(66,101)$. The above qualitative changes in functional connectivity patterns go hand in hand with a different nature of $\left[\mathrm{Ca}^{2+}\right]_{\mathrm{IC}}$ oscillations. Under low stimulatory conditions, on average the oscillations are present in a smaller fraction of cells, and they are rarer and more erratic. At glucose concentrations beyond $12 \mathrm{mM},\left[\mathrm{Ca}^{2+}\right]_{\mathrm{IC}}$ oscillations become more frequent, global, and coherent, resulting in functionally more connected networks $(66,142)$. Our findings seem to suggest that in future studies aimed at assessing functional heterogeneity under normal and pathological conditions, it seems to be advisable to use lower stimulatory concentrations of glucose than typically used in the literature, i.e., up to $12 \mathrm{mM}$. Beyond this level, many functional properties seem to saturate and differences between cells become much less well pronounced. It should be noted that in the present work, we did not analyze in detail the properties of the $\left[\mathrm{Ca}^{2+}\right]_{\mathrm{IC}}$ waves that are the synchronizing mechanism coordinating fast $\left[\mathrm{Ca}^{2+}\right]_{\mathrm{IC}}$ oscillations $(19,47,125,143)$. Such an analysis would enable us to also study the properties of the cells that initiate fast $\left[\mathrm{Ca}^{2+}\right]_{\mathrm{Ic}}$ oscillations, i.e., pacemakers. However, such an endeavour is technically and analytically more challenging and will be covered in a separate article.

\subsection{Deactivation}

Afer the end of stimulation, beta cells gradually suppressed their oscillatory activity, and their $\left[\mathrm{Ca}^{2+}\right]_{\mathrm{IC}}$ returned to the basal level. The spatiotemporal pattern of this "off" response showed clear glucose-dependence (Figure 5). In brief, after exposure to lower levels of glucose, the beta cells deactivated sooner and more homogeneously, i.e., with shorter first cell-any cell delays and in larger clusters than after exposure to higher glucose concentrations. To explain the observed behavior with respect to beta cell metabolism and intercellular coupling, further modelling and experimental studies are warranted. That being said, to our knowledge this is the first systematic and quantitative report on the glucose-dependence of beta cell deactivation and provides a reference point for future studies. It is reasonable to speculate that the longer delays and more heterogenous "off" responses in higher glucose are a direct consequence of a greater metabolic activation during stimulation and thus longer time required for the ATP production to fall below the stimulatory level. Noteworthy, changes in deactivation properties are present in $\mathrm{C} \times 36$ knockout mice, together with an increased basal and lower stimulated insulin secretion $(71,116,133)$ and in a genetic model of the metabolic syndrome, together with islet hypertrophy, changes in intercellular coupling, and insulin hypersecretion (39). This indicates that changes in deactivation, similarly to changes in activation and plateau activity could be an early marker of beta cell functional adaptation and dysfunction during development of diabetes $(63,81,141)$. Moreover, under normal conditions insulin and glucose levels oscillate in different species with a period on the order of magnitude of 10 minutes $(64,71,94)$ and the loss of these oscillations is an early marker of diabetes (93). Our current and previous research suggests that the loss of oscillations could at least partly be due to hyperglycemia per se, in the sense that beta cells become unable to turn off soon enough to allow for periods of silence between subsequent pulses (66). 


\subsection{Connecting the dots: relations between activation, plateau, and deactivation}

The temporal and spatial resolution in our current study, together with the large number of analyzed cells, gave us the opportunity to systematically look for the first time for a possible overlap between a cell's role during activation, plateau, and deactivation. More specifically, with respect to every parameter size, cells were divided into six parts, with the middle two sixths being pooled together into a majority with medium parameter values. In other words, our first-responders, most active cells, hubs, and first-deactivators are cells that belonged to the one sixth (or roughly $17 \%$ ) of cells with the smallest relative activation ranks, highest relative active times, most links in functional networks, and smallest relative deactivation ranks. Importantly, we wish to point out that paramater values were rather continuous, with no clear extremes. Also, we do not believe or wish to suggest that removing the cells with the highest parameter values would dramatically alter the collective behavior (49). Moreover, it remains to be investigated whether these roles are relatively constant in time or change dynamically (80). Finally, due to some recent confusion in the literature with respect to nomenclature, it shall be pointed out that the name "first-responders" pertains to the beginning of the transient activation, and that the name "pacemakers" shall be reserved for the cells that start the fast plateau $\left[\mathrm{Ca}^{2+}\right]_{1 \mathrm{c}}$ oscillations. As mentioned previously, due to technical reasons, the latter will be analyzed in a separate study.

All things considered, the first-responders tended to be among the most active cells during the plateau (and vice versa, the most active cells tended to have the shortest delays to activation; Figures $7 \mathrm{~B}$ and $\mathrm{S} 1 \mathrm{~A}$ ). The most active cells, in turn, tended to have longer delays to deactivation (and vice versa, the last-deactivators tended to have longer active times, Figures S1B and 7F). Further, the functionally most connected cells, i.e., the hubs, tended to have higher active times (in $8 \mathrm{mM}$ glucose, with no differences in $12 \mathrm{mM}$ glucose, Figure 7E), activate among the first (in $12 \mathrm{mM}$ glucose and not among the last in $8 \mathrm{mM}$ glucose, Figure $\mathrm{S} 1 \mathrm{E}$ ), and deactivate among the last (in $8 \mathrm{mM}$ glucose, with no differences in $12 \mathrm{mM}$ glucose, Figure S1F). There was no clear-cut direct relationship between activation and deactivation properties (Figures 7D and S1D). Moreover, in addition to the abovementioned relationship between most connected and most active cells, it should be pointed out that the least active cells had the least functional connections (in $8 \mathrm{mM}$ glucose and less than the majority in 12 $\mathrm{mM}$ glucose, Figure S1C). With regard to the relationship between most connected cells and activation, it can be added that first responders had the highest node degrees in $12 \mathrm{mM}$ glucose and higher node degrees than the last responders in $8 \mathrm{mM}$ glucose (Figure 7C). Finally, with regard to the relationship between most connected cells and deactivation, it seems that the first-deactivators are not among the most connected cells (Figure 7G).

Conceivably, a cell's ability to activate soon, maintain high levels of activity and functional connections during the plateau phase, and turn off late, compared with other cells, may have to do with its relative higher metabolic activity and rates of ATP production, relatively smaller K ATP conductance, which would enable it to reach the threshold for bursting activity sooner, and strong coupling with similarly excitable cells or weak coupling with much less excitable cells, which would not clamp it at resting membrane potential values too strongly, but help it 
activate and maintain active for longer. Validation of these hypotheses will require further testing by models and simultaneous or serial experimental assessment of metabolic and electrophysiological parameters and is beyond the reach of our current study. That said, we find it encouraging that our findings are compatible with previous modelling, electrophysiological and imaging studies, and may even help reconciliate some recent opposing views $(49,96,119,122,128,129)$. More specifically, different lines of evidence suggest that the functionally most connected cells are metabolically more active $(21,68,84$, $96,122,123)$. At the same time, our current and previous experimental and model findings that the parameter value distributions and functional behavior of cells are heteregoneous in a rather continuous manner $(67,68,87,101,139,140,142)$, with no clear-cut subpopulations, are compatible with the view that only a few cells with extreme parameter values are not necessary for normal beta cell activation, coordinated activity, and deactivation (49, 129). Again, we would like to underline that the terms "first-responders" and "hubs", as defined in this study, are not the same as "pacemakers". We believe that the term pacemakers shall be strictly used for cells initating well-defined plateau fast $\left[\mathrm{Ca}^{2+}\right]_{1 \mathrm{C}}$ oscillations. Our preliminary analyses suggest that the pacemaker role does not necessarily overlap with first-responders and hubs, which is again compatible with the view that pacemakers could be the metabolically least active cells (49).

In sum, we believe that beta cell heterogeneity with respect to activation, activity, and inactivation should become indisputable and that great strides shall be made in the future to better define terminology in this fascinating subfield of beta cell research, bring closer the researchers with different expertise and differing views on this matter, and to mechanistically explain the heterogeneity and define its clinical relevance.

\subsection{Acknowledgements}

We thank Maruša Rošer, Rudi Mlakar, and Maša Čater for their excellent technical assistance.

\subsection{Funding}

The work presented in this study was financially supported by the Slovenian Research Agency (research core funding nos. P3-0396 and 10-0029, as well as research projects nos. J3-9289, J49302, J1-9112, N3-0048 and N3-0133).

\subsection{Competing interests}

No competing interests exist.

\subsection{Author Contributions}

Conceptualization: Andraž Stožer, Marko Gosak, Marjan Slak Rupnik, Jurij Dolenšek

Formal analysis: Andraž Stožer, Maša Skelin Klemen, Marko Gosak, Lidija Križančić-Bombek, Viljem Pohorec, Jurij Dolenšek 
Software: Jurij Dolenšek, Marko Gosak

Experimental work: Andraž Stožer, Maša Skelin Klemen, Lidija Križančić-Bombek, Viljem Pohorec, Jurij Dolenšek

Funding acquisition: Andraž Stožer, Marjan Slak Rupnik

Project administration: Andraž Stožer, Marjan Slak Rupnik, Jurij Dolenšek

Supervision: Andraž Stožer, Jurij Dolenšek

Visualization: Andraž Stožer, Marko Gosak, Jurij Dolenšek

Writing - original draft: Andraž Stožer, Maša Skelin Klemen, Marko Gosak, Lidija KrižančićBombek, Viljem Pohorec Marjan Slak Rupnik, Jurij Dolenšek

Writing - review \& editing: Andraž Stožer, Marjan Slak Rupnik, Jurij Dolenšek

\section{References}

1. Accili D, Ahrén B, Boitard C, Cerasi E, Henquin JC, and Seino S. What ails the $\beta$-cell? Diabetes, Obesity and Metabolism 12: 1-3, 2010.

2. Adams MT, Reissaus CA, Szulczewski JM, Dwulet JM, Lyman MR, Sdao SM, Nimkulrat SD, Ponik SM, Merrins MJ, Benninger RKP, Mirmira RG, Linnemann AK, and Blum B. Islet architecture controls synchronous $\beta$ cell response to glucose in the intact mouse pancreas <em>in vivo</em>. bioRxiv 2019.2012.2011.873471, 2019.

3. Akalestou E, Suba K, Lopez-Noriega L, Georgiadou E, Chabosseau P, Leclerc I, Salem V, and Rutter GA. Intravital imaging of islet Ca2+ dynamics reveals enhanced $\beta$ cell connectivity after bariatric surgery in mice. Cold Spring Harbor Laboratory, 2020.

4. Akalestou E, Suba K, Lopez-Noriega L, Georgiadou E, Chabosseau P, Leclerc I, Salem V, and Rutter GA. Intravital imaging of islet $\mathrm{Ca}<\sup >2+</$ sup $>$ dynamics reveals enhanced $\beta$ cell connectivity after bariatric surgery in mice. bioRxiv 2020.2005.2005.078725, 2020.

5. Almaça J, Caicedo A, and Landsman L. Beta cell dysfunction in diabetes: the islet microenvironment as an unusual suspect. Diabetologia 63: 2076-2085, 2020.

6. Ammälä C, Eliasson L, Bokvist K, Larsson O, Ashcroft FM, and Rorsman P. Exocytosis elicited by action potentials and voltage-clamp calcium currents in individual mouse pancreatic B-cells. J Physiol 472: 665-688, 1993.

7. Antunes CM, Salgado AP, Rosário LM, and Santos RM. Differential patterns of glucoseinduced electrical activity and intracellular calcium responses in single mouse and rat pancreatic islets. Diabetes 49: 2028-2038, 2000.

8. Arrojo EDR, Roy B, and MacDonald PE. Molecular and functional profiling of human islets: from heterogeneity to human phenotypes. Diabetologia 63: 2095-2101, 2020.

9. Ashcroft SJ, Bassett JM, and Randle PJ. Insulin secretion mechanisms and glucose metabolism in isolated islets. Diabetes 21: 538-545, 1972.

10. Aslanidi OV, Mornev OA, Skyggebjerg O, Arkhammar P, Thastrup O, Sørensen MP, Christiansen PL, Conradsen K, and Scott AC. Excitation wave propagation as a possible mechanism for signal transmission in pancreatic islets of Langerhans. Biophysical journal 80: 1195-1209, 2001. 
11. Atwater I, Ribalet B, and Rojas E. Cyclic changes in potential and resistance of the betacell membrane induced by glucose in islets of Langerhans from mouse. J Physiol 278: 117-139, 1978.

12. Bader E, Migliorini A, Gegg M, Moruzzi N, Gerdes J, Roscioni SS, Bakhti M, Brandl E, Irmler M, Beckers J, Aichler M, Feuchtinger A, Leitzinger C, Zischka H, Wang-Sattler R, Jastroch M, Tschop M, Machicao F, Staiger H, Haring HU, Chmelova H, Chouinard JA, Oskolkov N, Korsgren O, Speier S, and Lickert H. Identification of proliferative and mature beta-cells in the islets of Langerhans. Nature 535: 430-434, 2016.

13. Barbosa RM, Silva AM, Tomé AR, Stamford JA, Santos RM, and Rosário LM. Control of pulsatile $5-\mathrm{HT}$ /insulin secretion from single mouse pancreatic islets by intracellular calcium dynamics. J Physiol 510: 135-143, 1998.

14. Barua AK, and Goel P. Isles within islets: The lattice origin of small-world networks in pancreatic tissues. Physica D: Nonlinear Phenomena 315: 49-57, 2016.

15. Bavamian S, Klee P, Britan A, Populaire C, Caille D, Cancela J, Charollais A, and Meda P. Islet-cell-to-cell communication as basis for normal insulin secretion. Diabetes, Obesity and Metabolism 9: 118-132, 2007.

16. Beauvois MC, Merezak C, Jonas J-C, Ravier MA, Henquin J-C, and Gilon P. Glucoseinduced mixed [ $\mathrm{Ca} 2+] \mathrm{c}$ oscillations in mouse $\beta$-cells are controlled by the membrane potential and the SERCA3 Ca2+-ATPase of the endoplasmic reticulum. American Journal of Physiology Cell Physiology 290: C1503-C1511, 2006.

17. Benninger RK, Hutchens T, Head WS, McCaughey MJ, Zhang M, Le Marchand SJ, Satin LS, and Piston DW. Intrinsic islet heterogeneity and gap junction coupling determine spatiotemporal ca(2+) wave dynamics. Biophysical journal 107: 2723-2733, 2014.

18. Benninger RK, and Piston DW. Cellular communication and heterogeneity in pancreatic islet insulin secretion dynamics. Trends in endocrinology and metabolism: TEM 2014.

19. Benninger RK, Zhang M, Head WS, Satin LS, and Piston DW. Gap junction coupling and calcium waves in the pancreatic islet. Biophysical journal 95: 5048-5061, 2008.

20. Benninger RKP, Head WS, Zhang M, Satin LS, and Piston DW. Gap junctions and other mechanisms of cell-cell communication regulate basal insulin secretion in the pancreatic islet. J Physiol 589: 5453-5466, 2011.

21. Benninger RKP, and Hodson DJ. New Understanding of $\beta$-Cell Heterogeneity and In Situ Islet Function. Diabetes 67: 537-547, 2018.

22. Bergsten P. Slow and fast oscillations of cytoplasmic $\mathrm{Ca} 2+$ in pancreatic islets correspond to pulsatile insulin release. American Journal of Physiology - Endocrinology And Metabolism 268: E282-E287, 1995.

23. Bergsten P, Grapengiesser E, Gylfe E, Tengholm A, and Hellman B. Synchronous oscillations of cytoplasmic $\mathrm{Ca} 2+$ and insulin release in glucose-stimulated pancreatic islets. Journal of Biological Chemistry 269: 8749-8753, 1994.

24. Bergsten $\mathbf{P}$, and Hellman $\mathbf{B}$. Glucose-induced amplitude regulation of pulsatile insulin secretion from individual pancreatic islets. Diabetes 42: 670-674, 1993.

25. Bertram R, Satin LS, and Sherman AS. Closing in on the Mechanisms of Pulsatile Insulin Secretion. Diabetes 67: 351-359, 2018.

26. Bertuzzi F, Davalli AM, Nano R, Socci C, Codazzi F, Fesce R, Di Carlo V, Pozza G, and Grohovaz F. Mechanisms of coordination of $\mathrm{Ca}^{2+}$ signals in pancreatic islet cells. Diabetes 48: 1971-1978, 1999. 
27. Boccaletti S, Latora V, Moreno Y, Chavez M, and Hwang DU. Complex networks: Structure and dynamics. Physics Reports 424: 175-308, 2006.

28. Bosco D, Haefliger J-A, and Meda P. Connexins: Key Mediators of Endocrine Function. Physiological Reviews 91: 1393-1445, 2011.

29. Bratanova-Tochkova TK, Cheng H, Daniel S, Gunawardana S, Liu Y-J, Mulvaney-Musa J, Schermerhorn T, Straub SG, Yajima H, and Sharp GWG. Triggering and Augmentation Mechanisms, Granule Pools, and Biphasic Insulin Secretion. Diabetes 51: S83-S90, 2002.

30. Cappon G, and Pedersen MG. Heterogeneity and nearest-neighbor coupling can explain small-worldness and wave properties in pancreatic islets. Chaos (Woodbury, NY) 26: 053103, 2016.

31. Carvalho CPF, Oliveira RB, Britan A, Santos-Silva JC, Boschero AC, Meda P, and Collares-Buzato CB. Impaired $\beta$-cell- $\beta$-cell coupling mediated by $\mathrm{Cx} 36$ gap junctions in prediabetic mice. American Journal of Physiology - Endocrinology And Metabolism 303: E144E151, 2012.

32. Cerasi E. Mechanisms of glucose stimulated insulin secretion in health and in diabetes: Some re-evaluations and proposals. Diabetologia 11: 1-13, 1975.

33. Chen C, Chmelova H, Cohrs CM, Chouinard JA, Jahn SR, Stertmann J, Uphues I, and Speier S. Alterations in beta-Cell Calcium Dynamics and Efficacy Outweigh Islet Mass Adaptation in Compensation of Insulin Resistance and Prediabetes Onset. Diabetes 65: 26762685, 2016.

34. Cherubini C, Filippi S, Gizzi A, and Loppini A. Role of topology in complex functional networks of beta cells. Physical review E, Statistical, nonlinear, and soft matter physics 92: 042702, 2015.

35. Cigliola V, Allagnat F, Berchtold LA, Lamprianou S, Haefliger JA, and Meda P. Role of Connexins and Pannexins in the Pancreas. Pancreas 44: 1234-1244, 2015.

36. Cigliola V, Chellakudam V, Arabieter W, and Meda P. Connexins and $\beta$-cell functions. Diabetes Research and Clinical Practice 99: 250-259, 2013.

37. Cook DL. Electrical pacemaker mechanisms of pancreatic islet cells. Federation proceedings 43: 2368-2372, 1984.

38. Cook DL, and Ikeuchi M. Tolbutamide as mimic of glucose on beta-cell electrical activity. ATP-sensitive K+ channels as common pathway for both stimuli. Diabetes 38: 416421, 1989.

39. Daraio T, Bombek LK, Gosak M, Valladolid-Acebes I, Klemen MS, Refai E, Berggren PO, Brismar K, Rupnik MS, and Bark C. SNAP-25b-deficiency increases insulin secretion and changes spatiotemporal profile of $\mathrm{Ca}(2+)$ oscillations in beta cell networks. Scientific reports 7 : 7744, 2017.

40. Dean PM, and Matthews EK. Glucose-induced electrical activity in pancreatic islet cells. J Physiol 210: 255-264, 1970.

41. Detimary P, Jonas JC, and Henquin JC. Possible links between glucose-induced changes in the energy state of pancreatic B cells and insulin release. Unmasking by decreasing a stable pool of adenine nucleotides in mouse islets. The Journal of Clinical Investigation 96: 17381745, 1995.

42. Dhumpa R, Truong TM, Wang X, Bertram R, and Roper MG. Negative feedback synchronizes islets of Langerhans. Biophysical journal 106: 2275-2282, 2014.

43. do Amaral MEC, Kravets V, Dwulet JM, Farnsworth NL, Piscopio R, Schleicher WE, Miranda JG, and Benninger RKP. Caloric Restriction recovers impaired $\beta$-cell- $\beta$-cell gap 
junction coupling, calcium oscillation coordination and insulin secretion in prediabetic mice. American journal of physiology Endocrinology and metabolism 2020.

44. Do OH, Low JT, Gaisano HY, and Thorn P. The secretory deficit in islets from $\mathrm{db} / \mathrm{db}$ mice is mainly due to a loss of responding beta cells. Diabetologia 57: 1400-1409, 2014.

45. Dolensek J, Rupnik MS, and Stozer A. Structural similarities and differences between the human and the mouse pancreas. Islets 7: e1024405, 2015.

46. Dolensek J, Spelic D, Klemen MS, Zalik B, Gosak M, Rupnik MS, and Stozer A. Membrane Potential and Calcium Dynamics in Beta Cells from Mouse Pancreas Tissue Slices: Theory, Experimentation, and Analysis. Sensors (Basel, Switzerland) 15: 27393-27419, 2015.

47. Dolenšek J, Stožer $A$, Skelin Klemen $M$, Miller EW, and Slak Rupnik $M$. The Relationship between Membrane Potential and Calcium Dynamics in Glucose-Stimulated Beta Cell Syncytium in Acute Mouse Pancreas Tissue Slices. PLoS ONE 8: e82374, 2013.

48. Duchen MR, Smith PA, and Ashcroft FM. Substrate-dependent changes in mitochondrial function, intracellular free calcium concentration and membrane channels in pancreatic beta-cells. Biochem J 294 ( Pt 1): 35-42, 1993.

49. Dwulet JM, Briggs JK, and Benninger RKP. Small subpopulations of $\beta$-cells do not drive islet oscillatory [Ca<sup $>2+</$ sup $>$ ] dynamics via gap junction communication. bioRxiv 2020.2010.2028.358457, 2020.

50. Dwulet JM, Ludin NWF, Piscopio RA, Schleicher WE, Moua O, Westacott MJ, and Benninger RKP. How Heterogeneity in Glucokinase and Gap-Junction Coupling Determines the Islet [Ca2+] Response. Biophysical journal 2019.

51. Farnsworth NL, and Benninger RK. New insights into the role of connexins in pancreatic islet function and diabetes. FEBS Lett 588: 1278-1287, 2014.

52. Farnsworth NL, Walter R, Piscopio RA, Schleicher WE, and Benninger RKP. Exendin-4 overcomes cytokine-induced decreases in gap junction coupling via protein kinase $A$ and Epac2 in mouse and human islets. The Journal of Physiology 597: 431-447, 2019.

53. Farnsworth NL, Walter RL, Hemmati A, Westacott MJ, and Benninger RK. Low Level Pro-inflammatory Cytokines Decrease Connexin36 Gap Junction Coupling in Mouse and Human Islets through Nitric Oxide-mediated Protein Kinase Cdelta. The Journal of biological chemistry 291: 3184-3196, 2016.

54. Fernandez J, and Valdeolmillos M. Synchronous glucose-dependent [Ca2+]i oscillations in mouse pancreatic islets of Langerhans recorded in vivo. FEBS Letters 477: 3336, 2000.

55. Frikke-Schmidt H, Arvan P, Seeley RJ, and Cras-Méneur C. Improved in vivo imaging method for individual islets across the mouse pancreas reveals a heterogeneous insulin secretion response to glucose. Scientific reports 11: 2021.

56. Gan WJ, Zavortink M, Ludick C, Templin R, Webb R, Ma W, Poronnik P, Parton RG, Gaisano HY, Shewan AM, and Thorn P. Cell polarity defines three distinct domains in pancreatic beta-cells. J Cell Sci 130: 143-151, 2017.

57. Gao ZY, Drews G, Nenquin M, Plant TD, and Henquin JC. Mechanisms of the stimulation of insulin release by arginine-vasopressin in normal mouse islets. The Journal of biological chemistry 265: 15724-15730, 1990.

58. Gilon $\mathbf{P}$, Chae H-Y, Rutter GA, and Ravier MA. Calcium signaling in pancreatic $\beta$-cells in health and in Type 2 diabetes. Cell Calcium 56: 340-361, 2014.

59. Gilon P, and Henquin JC. Influence of membrane potential changes on cytoplasmic $\mathrm{Ca} 2+$ concentration in an electrically excitable cell, the insulin-secreting pancreatic B-cell. Journal of Biological Chemistry 267: 20713-20720, 1992. 
60. Gilon P, Ravier MA, Jonas J-C, and Henquin J-C. Control Mechanisms of the Oscillations of Insulin Secretion In Vitro and In Vivo. Diabetes 51: S144-S151, 2002.

61. Gilon P, Shepherd RM, and Henquin JC. Oscillations of secretion driven by oscillations of cytoplasmic $\mathrm{Ca}^{2+}$ as evidenced in single pancreatic islets. Journal of Biological Chemistry 268: 22265-22268, 1993.

62. Gonzalez A, Merino B, Marroqui L, Neco P, Alonso-Magdalena P, Caballero-Garrido E, Vieira E, Soriano S, Gomis R, Nadal A, and Quesada I. Insulin hypersecretion in islets from diet-induced hyperinsulinemic obese female mice is associated with several functional adaptations in individual beta-cells. Endocrinology 154: 3515-3524, 2013.

63. Gonzalez A, Merino B, Marroquí L, Ñeco P, Alonso-Magdalena P, Caballero-Garrido E, Vieira E, Soriano S, Gomis R, Nadal A, and Quesada I. Insulin Hypersecretion in Islets From Diet-Induced Hyperinsulinemic Obese Female Mice Is Associated With Several Functional Adaptations in Individual $\beta$-Cells. Endocrinology 154: 3515-3524, 2013.

64. Goodner C, Walike B, Koerker D, Ensinck J, Brown A, Chideckel E, Palmer J, and Kalnasy L. Insulin, glucagon, and glucose exhibit synchronous, sustained oscillations in fasting monkeys. Science 195: 177-179, 1977.

65. Gosak M, Markovic R, Dolensek J, Rupnik MS, Marhl M, Stozer A, and Perc M. Loosening the shackles of scientific disciplines with network science: Reply to comments on "Network science of biological systems at different scales: A review". Physics of life reviews 24: 162-167, 2018.

66. Gosak M, Markovic R, Dolensek J, Slak Rupnik M, Marhl M, Stozer A, and Perc M. Network science of biological systems at different scales: A review. Physics of life reviews 24: 118-135, 2018.

67. Gosak M, Stozer A, Markovic R, Dolensek J, Perc M, Rupnik MS, and MarhI M. Critical and Supercritical Spatiotemporal Calcium Dynamics in Beta Cells. Front Physiol 8: 1106, 2017. 68. Gosak M, Stožer A, Markovič R, Dolenšek J, Marhl M, Slak Rupnik $\mathbf{M}$, and Perc $\mathbf{M}$. The relationship between node degree and dissipation rate in networks of diffusively coupled oscillators and its significance for pancreatic beta cells. Chaos (Woodbury, NY) 25: 073115, 2015.

69. Grapengiesser E, Gylfe E, and Hellman B. Glucose-induced oscillations of cytoplasmic $\mathrm{Ca} 2+$ in the pancreatic $\beta$-cell. Biochemical and Biophysical Research Communications 151: 1299-1304, 1988.

70. Gylfe E. Nutrient secretagogues induce bimodal early changes in cytoplasmic calcium of insulin-releasing ob/ob mouse beta-cells. Journal of Biological Chemistry 263: 13750-13754, 1988.

71. Head WS, Orseth ML, Nunemaker CS, Satin LS, Piston DW, and Benninger RK. Connexin-36 gap junctions regulate in vivo first- and second-phase insulin secretion dynamics and glucose tolerance in the conscious mouse. Diabetes 61: 1700-1707, 2012.

72. Hellman B, Gylfe E, Bergsten P, Grapengiesser E, Lund P, Berts A, Tengholm A, Pipeleers $\mathbf{D}$, and Ling Z. Glucose induces oscillatory $C a<\sup >2+</$ sup $>$ signalling and insulin release in human pancreatic beta cells. Diabetologia 37: S11-S20, 1994.

73. Henquin J-C. The dual control of insulin secretion by glucose involves triggering and amplifying pathways in $\beta$-cells. Diabetes Research and Clinical Practice 93, Supplement 1: S27S31, 2011.

74. Henquin J-C, Nenquin M, Stiernet $\mathbf{P}$, and Ahren B. In Vivo and In Vitro Glucose-Induced Biphasic Insulin Secretion in the Mouse. Diabetes 55: 441-451, 2006. 
75. Henquin J. Regulation of insulin secretion: a matter of phase control and amplitude modulation. Diabetologia 52: 739-751, 2009.

76. Henquin JC. Adenosine triphosphate-sensitive $\mathrm{K}+$ channels may not be the sole regulators of glucose-induced electrical activity in pancreatic B-cells. Endocrinology 131: 127131, 1992.

77. Hodson DJ, Legros C, Desarmenien MG, and Guerineau NC. Roles of connexins and pannexins in (neuro)endocrine physiology. Cellular and molecular life sciences : CMLS 72: 2911-2928, 2015.

78. Hodson DJ, Mitchell RK, Bellomo EA, Sun G, Vinet L, Meda P, Li D, Li WH, Bugliani M, Marchetti P, Bosco D, Piemonti L, Johnson P, Hughes SJ, and Rutter GA. Lipotoxicity disrupts incretin-regulated human beta cell connectivity. J Clin Invest 123: 4182-4194, 2013.

79. Hodson DJ, Schaeffer M, Romano N, Fontanaud P, Lafont C, Birkenstock J, Molino F, Christian H, Lockey J, Carmignac D, Fernandez-Fuente M, Le Tissier P, and Mollard P. Existence of long-lasting experience-dependent plasticity in endocrine cell networks. Nat Commun 3: 605, 2012.

80. Idevall-Hagren $\mathbf{O}$, and Tengholm A. Metabolic regulation of calcium signaling in beta cells. Seminars in Cell \& Developmental Biology 103: 20-30, 2020.

81. Irles E, Neco P, Lluesma M, Villar-Pazos S, Santos-Silva JC, Vettorazzi JF, AlonsoMagdalena P, Carneiro EM, Boschero AC, Nadal A, and Quesada I. Enhanced glucose-induced intracellular signaling promotes insulin hypersecretion: pancreatic beta-cell functional adaptations in a model of genetic obesity and prediabetes. Mol Cell Endocrinol 404: 46-55, 2015.

82. Jaffredo M, Bertin E, Pirog A, Puginier E, Gaitan J, Oucherif S, Lebreton F, Bosco D, Catargi B, Cattaert D, Renaud S, Lang J, and Raoux M. Dynamic uni- and Multicellular Patterns Encode Biphasic Activity in Pancreatic Islets. Diabetes 2021.

83. Jain R, and Lammert E. Cell-cell interactions in the endocrine pancreas. Diabetes, Obesity and Metabolism 11: 159-167, 2009.

84. Johnston NR, Mitchell RK, Haythorne E, Pessoa MP, Semplici F, Ferrer J, Piemonti L, Marchetti P, Bugliani M, Bosco D, Berishvili E, Duncanson P, Watkinson M, Broichhagen J, Trauner D, Rutter GA, and Hodson DJ. Beta Cell Hubs Dictate Pancreatic Islet Responses to Glucose. Cell Metab 24: 389-401, 2016.

85. Jonkers FC, and Henquin J-C. Measurements of Cytoplasmic Ca2+ in Islet Cell Clusters Show That Glucose Rapidly Recruits $\beta$-Cells and Gradually Increases the Individual Cell Response. Diabetes 50: 540-550, 2001.

86. Klueh U, Liu Z, Cho B, Ouyang T, Feldman B, Henning TP, Kaur M, and Kreutzer D. Continuous glucose monitoring in normal mice and mice with prediabetes and diabetes. Diabetes technology \& therapeutics 8: 402-412, 2006.

87. Korošak D, Jusup M, Podobnik B, Stolver Av, Dolen \vek J, Holme P, and Marjan. Autopoietic influence hierarchies in pancreatic \$|beta\$-cells. arXiv pre-print server 2021.

88. Korošak D, and Slak Rupnik M. Collective Sensing of $\beta$-Cells Generates the Metabolic Code. Frontiers in Physiology 9: 2018.

89. Kotas Maya E, and Medzhitov R. Homeostasis, Inflammation, and Disease Susceptibility. Cell 160: 816-827, 2015.

90. Kowalski GM, and Bruce CR. The regulation of glucose metabolism: implications and considerations for the assessment of glucose homeostasis in rodents. Am J Physiol-Endoc M 307: E859-E871, 2014. 
91. Kravets V, Dwulet JM, Schleicher WE, Hodson DJ, Davis AM, Piscopio RA, Sticco-Ivins $M$, and Benninger RKP. Functional architecture of the pancreatic islets: First responder cells drive the first-phase [Ca2+] response. Cold Spring Harbor Laboratory, 2020.

92. Lammert E, and Thorn P. The Role of the Islet Niche on Beta Cell Structure and Function. J Mol Biol 432: 1407-1418, 2020.

93. Lang DA, Matthews DR, Burnett M, and Turner RC. Brief, Irregular Oscillations of Basal Plasma Insulin and Glucose Concentrations in Diabetic Man. Diabetes 30: 435-439, 1981.

94. Lang DA, Matthews DR, Peto J, and Turner RC. CYCLIC OSCILLATIONS OF BASAL PLASMA-GLUCOSE AND INSULIN CONCENTRATIONS IN HUMAN-BEINGS. New England Journal of Medicine 301: 1023-1027, 1979.

95. Lebreton F, Pirog A, Belouah I, Bosco D, Berney T, Meda P, Bornat Y, Catargi B, Renaud S, Raoux M, and Lang J. Slow potentials encode intercellular coupling and insulin demand in pancreatic beta cells. Diabetologia 2015.

96. Lei C-L, Kellard JA, Hara M, Johnson JD, Rodriguez B, and Briant UB. Beta-cell hubs maintain Ca2+ oscillations in human and mouse islet simulations. Islets 10: 151-167, 2018.

97. Low JT, Mitchell JM, Do OH, Bax J, Rawlings A, Zavortink M, Morgan G, Parton RG, Gaisano HY, and Thorn P. Glucose principally regulates insulin secretion in mouse islets by controlling the numbers of granule fusion events per cell. Diabetologia 56: 2629-2637, 2013.

98. MacDonald PE, Joseph JW, and Rorsman P. Glucose-sensing mechanisms in pancreatic B-cells. Philosophical Transactions of the Royal Society B: Biological Sciences 360: 2211-2225, 2005.

99. MacDonald PE, and Rorsman P. Oscillations, Intercellular Coupling, and Insulin Secretion in Pancreatic $\beta$ Cells. PLoS Biol 4: e49, 2006.

100. Mari A, and Ferrannini E. Beta-cell function assessment from modelling of oral tests: an effective approach. Diabetes, obesity \& metabolism 10 Suppl 4: 77-87, 2008.

101. Markovic R, Stozer A, Gosak M, Dolensek J, Marhl M, and Rupnik MS. Progressive glucose stimulation of islet beta cells reveals a transition from segregated to integrated modular functional connectivity patterns. Scientific reports 5: 7845, 2015.

102. Mazzaccara C, Labruna G, Cito G, Scarfo M, De Felice M, Pastore L, and Sacchetti L. Age-Related Reference Intervals of the Main Biochemical and Hematological Parameters in C57BL/6J, 129SV/EV and C3H/HeJ Mouse Strains. PLoS ONE 3: e3772, 2008.

103. Meda P. Gap junction proteins are key drivers of endocrine function. Biochimica et Biophysica Acta (BBA) - Biomembranes 1860: 124-140, 2018.

104. Meissner HP, and Schmelz H. Membrane potential of beta-cells in pancreatic islets. Pflügers Archiv European Journal of Physiology 351: 195-206, 1974.

105. Moreno AP, Berthoud VM, Pérez-Palacios G, and Pérez-Armendariz EM. Biophysical evidence that connexin-36 forms functional gap junction channels between pancreatic mouse ß-cells. American Journal of Physiology - Endocrinology And Metabolism 288: E948-E956, 2005.

106. Nasteska D, and Hodson DJ. The role of beta cell heterogeneity in islet function and insulin release. J Mol Endocrinol 61: R43-r60, 2018.

107. Nicholls DG. The Pancreatic beta-Cell: A Bioenergetic Perspective. Physiol Rev 96: 1385-1447, 2016.

108. O'Connor MD, Landahl H, and Grodsky GM. Comparison of storage- and signal-limited models of pancreatic insulin secretion. American Journal of Physiology - Regulatory, Integrative and Comparative Physiology 238: R378-R389, 1980. 
109. Pedersen Morten G, Mosekilde E, Polonsky Kenneth S, and Luciani Dan S. Complex Patterns of Metabolic and Ca2+ Entrainment in Pancreatic Islets by Oscillatory Glucose. Biophysical journal 105: 29-39, 2013.

110. Pedersen MG, Tagliavini A, and Henquin J-C. Calcium signaling and secretory granule pool dynamics underlie biphasic insulin secretion and its amplification by glucose: experiments and modeling. Am J Physiol-Endoc M 316: E475-E486, 2019.

111. Pedersen MG, Tagliavini A, and Henquin JC. Calcium signaling and secretory granule pool dynamics underlie biphasic insulin secretion and its amplification: experiments and modeling. American journal of physiology Endocrinology and metabolism 2019.

112. Pipeleers D, De Mesmaeker I, Robert T, and Van Hulle F. Heterogeneity in the BetaCell Population: a Guided Search Into Its Significance in Pancreas and in Implants. Current Diabetes Reports 17: 2017.

113. Pipeleers D, Kiekens R, Ling Z, Wilikens A, and Schuit F. Physiologic relevance of heterogeneity in the pancreatic beta-cell population. Diabetologia 37: S57-S64, 1994.

114. Pipeleers DG. Heterogeneity in pancreatic beta-cell population. Diabetes 41: 777-781, 1992.

115. Pratley RE, and Weyer C. The role of impaired early insulin secretion in the pathogenesis of Type II diabetes mellitus. Diabetologia 44: 929-945, 2001.

116. Ravier MA, Güldenagel M, Charollais A, Gjinovci A, Caille D, Söhl G, Wollheim CB, Willecke K, Henquin J-C, and Meda P. Loss of Connexin36 Channels Alters $\beta$-Cell Coupling, Islet Synchronization of Glucose-Induced $\mathrm{Ca} 2+$ and Insulin Oscillations, and Basal Insulin Release. Diabetes 54: 1798-1807, 2005.

117. Rorsman P, and Ashcroft FM. Pancreatic $\beta$-Cell Electrical Activity and Insulin Secretion: Of Mice and Men. Physiological Reviews 98: 117-214, 2018.

118. Roscioni SS, Migliorini A, Gegg M, and Lickert H. Impact of islet architecture on betacell heterogeneity, plasticity and function. Nature reviews Endocrinology 12: 695-709, 2016.

119. Rutter GA, Georgiadou E, Martinez-Sanchez A, and Pullen TJ. Metabolic and functional specialisations of the pancreatic beta cell: gene disallowance, mitochondrial metabolism and intercellular connectivity. Diabetologia 63: 1990-1998, 2020.

120. Rutter GA, and Hodson DJ. Beta cell connectivity in pancreatic islets: a type 2 diabetes target? Cellular and molecular life sciences : CMLS 2014.

121. Rutter GA, and Hodson DJ. Minireview: intraislet regulation of insulin secretion in humans. Molecular endocrinology (Baltimore, Md) 27: 1984-1995, 2013.

122. Rutter GA, Ninov N, Salem V, and Hodson DJ. Comment on Satin et al. "Take Me To Your Leader": An Electrophysiological Appraisal of the Role of Hub Cells in Pancreatic Islets. Diabetes 2020;69:830-836. Diabetes 69: e10-e11, 2020.

123. Salem V, Silva LD, Suba K, Georgiadou E, Neda Mousavy Gharavy S, Akhtar N, MartinAlonso A, Gaboriau DCA, Rothery SM, Stylianides T, Carrat G, Pullen TJ, Singh SP, Hodson DJ, Leclerc I, Shapiro AMJ, Marchetti P, Briant LB, Distaso W, Ninov N, and Rutter GA. Leader $\beta$-cells coordinate Ca2+ dynamics across pancreatic islets in vivo. Nature Metabolism 1: 615629, 2019.

124. Sanchez-Andres JV, Pomares R, and Malaisse WJ. Adaptive short-term associative conditioning in the pancreatic $\beta$-cell. Physiological reports 8: 2020.

125. Santos RM, Rosario LM, Nadal A, Garcia-Sancho J, Soria B, and Valdeolmillos M. Widespread synchronous Ca oscillations due to bursting electrical activity in single pancreatic islets. Pflügers Archiv European Journal of Physiology 418: 417-422, 1991. 
126. Satin LS. Localized calcium influx in pancreatic beta-cells: its significance for Ca2+dependent insulin secretion from the islets of Langerhans. Endocr 13: 251-262, 2000.

127. Satin LS, Butler PC, Ha J, and Sherman AS. Pulsatile insulin secretion, impaired glucose tolerance and type 2 diabetes. Molecular aspects of medicine 2015.

128. Satin LS, and Rorsman P. Response to Comment on Satin et al. "Take Me To Your Leader": An Electrophysiological Appraisal of the Role of Hub Cells in Pancreatic Islets. Diabetes 2020;69:830-836. Diabetes 69: e12-e13, 2020.

129. Satin LS, Zhang $\mathbf{Q}$, and Rorsman P. "Take Me To Your Leader": An Electrophysiological Appraisal of the Role of Hub Cells in Pancreatic Islets. Diabetes 69: 830-836, 2020.

130. Scarl RT, Corbin KL, Vann NW, Smith HM, Satin LS, Sherman A, and Nunemaker CS. Intact pancreatic islets and dispersed beta-cells both generate intracellular calcium oscillations but differ in their responsiveness to glucose. Cell Calcium 83: 102081, 2019.

131. Skelin Klemen $\mathbf{M}$, Dolenšek J, Slak Rupnik $\mathbf{M}$, and Stožer $\mathbf{A}$. The Triggering Pathway to Insulin Secretion: Functional Similarities and Differences Between the Human and the Mouse Beta Cells and their Translational Relevance. Islets 00-00, 2017.

132. Skelin M, and Rupnik M. cAMP increases the sensitivity of exocytosis to Ca2+ primarily through protein kinase A in mouse pancreatic beta cells. Cell Calcium 49: 89-99, 2011.

133. Speier S, Gjinovci A, Charollais A, Meda P, and Rupnik M. Cx36-Mediated Coupling Reduces $\beta$-Cell Heterogeneity, Confines the Stimulating Glucose Concentration Range, and Affects Insulin Release Kinetics. Diabetes 56: 1078-1086, 2007.

134. Speier S, Nyqvist D, Cabrera O, Yu J, Molano RD, Pileggi A, Moede T, Kohler M, Wilbertz J, Leibiger B, Ricordi C, Leibiger IB, Caicedo A, and Berggren P-O. Noninvasive in vivo imaging of pancreatic islet cell biology. Nat Med 14: 574-578, 2008.

135. Speier S, Nyqvist D, Kohler M, Caicedo A, Leibiger IB, and Berggren PO. Noninvasive high-resolution in vivo imaging of cell biology in the anterior chamber of the mouse eye. Nat Protoc 3: 1278-1286, 2008.

136. Speier S, and Rupnik M. A novel approach to in situ characterization of pancreatic ßcells. Pflügers Archiv European Journal of Physiology 446: 553-558, 2003.

137. Stamper IJ, Jackson E, and Wang X. Phase transitions in pancreatic islet cellular networks and implications for type-1 diabetes. Physical review E, Statistical, nonlinear, and soft matter physics 89: 012719, 2014.

138. Stamper IJ, and Wang $\mathbf{X}$. Integrated multiscale mathematical modeling of insulin secretion reveals the role of islet network integrity for proper oscillatory glucose-dose response. J Theor Biol 2019.

139. Stožer A, Dolenšek J, and Rupnik MS. Glucose-Stimulated Calcium Dynamics in Islets of Langerhans in Acute Mouse Pancreas Tissue Slices. PLOS ONE 8: e54638, 2013.

140. Stožer $A$, Gosak $M$, Dolenšek J, Perc $M$, Marhl $M$, Rupnik MS, and Korošak D. Functional Connectivity in Islets of Langerhans from Mouse Pancreas Tissue Slices. PLoS Comput Biol 9: e1002923, 2013.

141. Stožer A, Hojs R, and Dolenšek J. Beta Cell Functional Adaptation and Dysfunction in Insulin Resistance and the Role of Chronic Kidney Disease. Nephron 2019.

142. Stožer A, Markovič R, Dolenšek J, Perc $M$, Marhl M, Slak Rupnik $M$, and Gosak $M$. Heterogeneity and Delayed Activation as Hallmarks of Self-Organization and Criticality in Excitable Tissue. Frontiers in Physiology 10: 2019.

143. Šterk M, Dolenšek J, Bombek LK, Markovič R, Zakelšek D, Perc M, Pohorec V, Stožer A, and Gosak M. Assessing the origin and velocity of $\mathrm{Ca} 2+$ waves in three-dimensional tissue: 
Insights from a mathematical model and confocal imaging in mouse pancreas tissue slices. Communications in Nonlinear Science and Numerical Simulation 93: 105495, 2021.

144. Tang S-C, Jessup CF, and Campbell-Thompson M. The Role of Accessory Cells in Islet Homeostasis. Current Diabetes Reports 18: 2018.

145. Westacott MJ, Farnsworth NL, St Clair JR, Poffenberger G, Heintz A, Ludin NW, Hart NJ, Powers AC, and Benninger RKP. Age-Dependent Decline in the Coordinated $[\mathrm{Ca}(2+)]$ and Insulin Secretory Dynamics in Human Pancreatic Islets. Diabetes 66: 2436-2445, 2017.

146. Westacott MJ, Ludin NWF, and Benninger RKP. Spatially Organized beta-Cell Subpopulations Control Electrical Dynamics across Islets of Langerhans. Biophysical journal 113: 1093-1108, 2017.

147. Zavala E, Wedgwood KCA, Voliotis M, Tabak J, Spiga F, Lightman SL, and TsanevaAtanasova K. Mathematical Modelling of Endocrine Systems. Trends in Endocrinology \& Metabolism 30: 244-257, 2019. 